\title{
2009-2017 Arası Küresel Sistemin Güvenlik Dönüşümü: Tek Kutupluluk Çok Kutupluluğa Karşı
}

\author{
Security Transformation of the Global System \\ between 2009 and 2017: Unipolarity vs. Multipolarity
}

\author{
Ferahşan GENÇKAYA*
}

$\ddot{O} z$

Soğuk Savas sonrast dönemde sistemde tek süper güç olarak bulunan $A B D$ oluşturduğu ittifaklar, kurumlar ve jeopolitik pazarlklar aracilğgyla hegemonik bir düzen kurmuştur. $A B D$ oluşturduğu bu düzende sahip olduğu askerî güc, kurduğu bölgesel ittifaklar ve yaydĭg kültürel yumuşak gücün avantajin kullanarak kendisini dünya politikasinn merkezinde konumlandirmıştr. Bu tek kutuplu sistemde uluslararası normlar, insan haklar, finansal sistem ve hükümet davranıslar büyük ölçüde $A B D$ tarafindan tasarlanmıs, sahiplenilmis ve bu uygulamalar diğer devletlerin siyasi ve hukuksal alanlarna yaynlmiştr. Ancak 2000'li ynllardan itibaren uluslararast sistemde meydana gelen yeni gelişmeler ve güvenlik sorunlar, $A B D$ tekelinde bulunan gücün yavas fakat aşamah olarak yeniden dağttllmasina neden olmuştur. Bu çalşmanin amacı, ABD'de Obama dönemi olarak bilinen 2009-2017 yllar arasinda uluslararası sistemde tek kutupluluğun belirgin şekilde zaynflamasina işaret eden ve küresel güç dengesinde değişime sebep olan önemli gelişmelerin neoklasik realizm teorik çerçevesi ile incelenmesidir. Çalsşmada uluslararast sistemdeki tek kutupluluğun dönüşüm süreci küresel ekonomik krizin yansımalar, Çin'in küresel aktör olarak yükselişi ve Rusya'nın küresel nüfuzunun belirginleşmesi bağlaminda ele alnmaktadrr. Çalş̧ma sonucunda, uluslararast sistemdeki yapısal geçisininin devam ettiği ve bu geçis döneminde $A B D$-Çin ilişkilerinin rekabet potansiyeli taşıdiğ tespit edilmiştir.

Anahtar Kelimeler: Uluslararası Sistem, Güvenlik, Hegemonya, ABD, Neoklasik Realizm.

* Doktora Öğrencisi, Marmara Üniversitesi, Sosyal Bilimler Enstitüsü, Siyaset Bilimi ve Uluslararası İlişkiler ABD, Uluslararası İlişkiler Bilim Dalı, İstanbul, Türkiye, ORCID: 0000-0002-7779-5476, e-posta: ferahsan@gmail.com.

Geliş Tarihi / Submitted: 06.02.2021

Kabul Tarihi / Accepted: 20.02.2021 


\section{Abstract}

After the Cold War, the US, as the only superpower in the system, created a hegemonic system through alliances, institutions, and geopolitical negotiations. In this new world order, the US has positioned itself at the center of world politics by taking advantage of its military power, regional alliances, and cultural soft power. In this unipolar system, international norms, human rights, financial systems, and the behaviors of the governments have been largely designed and owned by the US and these practices have spread to the political and legal spheres of other states. However, since the 2000s, new developments in the international system leads to slow but gradual redistribution of the power, which was under US monopoly. The purpose of this study is to examine the important developments that point out to the weakening of unipolarity in the international system between 2009 and 2017, known as the Obama era, with the theoretical framework of neoclassical realism. In the study, the transformation process of unipolarity in the international system is discussed in the context of the reflections of the global economic crisis, the rise of China as a global actor, and the prominence of Russia's global influence. As a result of the study, it has been determined that the structural transition of the international system continues and the Sino-US relations has a competitive potential.

Keywords: International System, Security, Hegemony, the US, Neoclassical Realism.

\section{Giriş}

Sovyetler Birliği’nin çöküşü ile birlikte iki kutuplu sistemin sona ermesini takip eden yıllardan bu yana, uluslararası ilişkiler literatüründe uluslararası sistemin dönüşümü ile ilgili olarak oldukça fazla analiz yapılmıştır. Uluslararası sistemin çok kutuplu niteliği ile ilgili olarak yapılan teorik çalışmalar ise özellikle Soğuk Savaş Sonrası dönemde hız kazanmıştır. Örneğin Ole Waever uluslararası güç dağılımında ABD'nin birinci sırada yer aldığını vurgularken; $A B$, Japonya, Çin ve Rusya gibi bölgesel güçlerin ise ikinci kademe bir konumda faaliyet göstermeye devam ettiklerini belirtmiştir. Waever, 2003 yılından sonraki dönemde meydana gelen yeni gelişmelerle birlikte sistemin değişen doğası gereği $\mathrm{ABD}$ ile diğer güçler arasındaki boşluğun kapanmasının bölgesel güvenlik alanındaki rekabeti daha çekişmeli hale getirdiğini belirtmiştir. ${ }^{1}$ Benzer şekilde,

\footnotetext{
${ }^{1}$ Ole Wæver, "International Leadership after the Demise of the Last Superpower: System Structure and Stewardship", Chinese Political Science Review, 2017, Sayı 2/4, 452-476, s. 471.
} 
2009-2017 Arası Küresel Sistemin Güvenlik Dönüşümü:

Tek Kutupluluk Çok Kutupluluğa Karşı

Christopher Layne 1993 yılında kaleme aldığı makalesinde uluslararası sistemde yeni büyük güçlerin kaçınılmaz olarak ortaya çıkacağını ve "Pax Amerikana"nın sona ereceğini öngörmüştür. ${ }^{2}$ Mearsheimer da eserlerinde Çin'in bölgesel bir hegemon haline geldiğini belirterek, yakın gelecekte ABD hegemonyasına $^{3}$ tehdit oluşturacağına dikkat çekmiş ve özellikle AsyaPasifik bölgesinde ABD ile rekabet edeceği öngörüsünde bulunmuştur. ${ }^{4}$

Fareed Zakaria ise çok kutupluluğa geçişin, büyük ölçüde "diğer ülkelerin (The Rest) yükselişinden" kaynaklandığına işaret etmiştir. ${ }^{5}$ Richard Haas diğer yazarlardan farklı olarak, uluslararası sistemde tek bir devletin sisteme tam anlamiyla egemen olamaması sebebiyle sistemi "kutupsuz (non-polar)" olarak tanımlamıştır. Sistemin belli bir devletin hâkimiyetinden ziyade, çeşitli alanlarda farklı kabiliyetlere sahip olan düzinelerce aktör tarafından yönetildiğini vurgulamıştır. ${ }^{6}$ Haas'ın bu yaklaşımı devletler arasındaki artan karşılıklı bağımlılık örnek gösterilerek eleştirilmiş ve uluslararası sistemde çok kutupluluğun devam ettiği ileri sürülmüştür. ${ }^{7}$ Bütün bu tartışmaların yanı sıra, Amitav Acharya hegemonya ile bölgesel kutuplar arasındaki ilişkiye vurgu yapmış ve uluslararası sistemin tanımı ile ilgili olarak "regiopolarity" kavramını kullanmıştır. Acharya, ülkelerin bulundukları bölgenin büyük gücü olması durumu olarak

2 Christopher Layne, "The Unipolar Illusion: Why New Great Powers will Rise", International Security, 1993, Say1 17/4, 5-51, s. 47.

3 Siyaset biliminde hegemonya kavramı ilk kez eleştirel teorinin temsilcilerinden Antonio Gramsci tarafindan kapsamlı biçimde tanımlanarak öne çıkarılmıştır. Gramsci'nin iktidar analizinin çatı kavramını oluşturan hegemonya, fiziki güç ya da zor kullanma yoluyla entelektüel, ahlaki ve kültürel ikna ya da rızayı birleştiren sosyal ve siyasal bir kontrol tarzıdır. Gramsci, hegemonik düzenin en belirgin özelliği olarak zor kullanmadan ziyade rızanın hâkim oluşunu vurgulamıştır. Neoklasik realizm ise hegemonyayı güç dengesi bağlamında kullanmakta ve bu bakımdan Gramsci'den daha farklı bir amaçla kullanmaktadır. Makalede hegemonya kavramı, neoklasik realizmin ana argümanları çerçevesinde "bir devletin askerî yeteneklerinin yanı sıra ekonomik ve kültürel normları da yurt dışına yansıtabilir olma yeteneği” olarak tanımlanmaktadır.

${ }^{4}$ John Mearsheimer, "The Gathering Storm: China's Challenge to US Power in Asia", The Chinese Journal of International Politics, 2010, Say1 3/4, 381-396, s. 390.

${ }^{5}$ Fareed Zakaria, The Post-American World and The Rise of The Rest, Penguin Books, London, 2008, s. 2.

${ }^{6}$ Richard N. Haas, “The Age of Nonpolarity: What will Follow US Dominance?", Foreign Affairs, 2008, Say1 87/3, 44-56, s. 49.

${ }^{7}$ Stephen G. Brooks, "Reshaping the World Order", Foreign Affairs, 2009, Say1 88/2, 49-63, s. 57.

8 Amitav Acharya, Regional Worlds in a Post-Hegemonic Era, Spirit Working Papers, Bordeaux, 2009, s. 24. 
tanımladığı bu yeni kavramın uluslararası sistemin yeni düzeninde öne çıkan tanımlama modeli olacağını iddia etmiştir. ${ }^{9}$ Kısacası uluslararası sistemin artık ABD hâkimiyetindeki tek kutuplu sistemden farklılaştığını kabul eden tüm bu yazarlar, sistemin çok kutupluluğunun tanımlanması konusunda ise birbirlerinden farklı kavramlar üretmişlerdir.

Sovyetler Birliği'nin çöküşü ve Almanya'nın yeniden birleşmesi sonrasında oluşan refah döneminin etkileri on yıl kadar sürmüştür. Soğuk Savaş sonrası dönemde bir bakıma alternatifsiz bir liberal "Leviathan" görevini üstlenen $\mathrm{ABD}$, böylesi bir sistemde ülkenin değer odaklı diş politika tarzını küreselleştirirken, kurucularının normatif ilkelerini de uygulamayı hedeflemiştir. ${ }^{10}$ Nitekim ABD bu dönemde Dünya Ticaret Örgütü (DTÖ), Uluslararası Ceza Mahkemesi (UCM) ve diğer küresel yönetişim merkezlerinin oluşturulmasına öncülük etmiştir. $\mathrm{Bu}$ yeni düzende uluslararası sitemdeki devletler egemenliklerini korumaya devam ederken, birbirleriyle kârlı ticaret bağlarını sürdürmek için liberal düzenin kurallarını takip etmeye özen göstermişlerdir. Yine de bazı devletlerden bu düzene alternatif oluşturmak isteyen çeşitli girişimler gelmiştir. Christopher Layne, devletlerin $\mathrm{ABD}$ liberal düzeninin boyunduruğundan kurtulma davranışlarını "tasma kayması (leash slipping)" olarak adlandırmıştır. ${ }^{11}$ Layne'e göre, ABD’nin hegemonya arayışı uluslararası sistemdeki güç dağılımı odaklı geleneksel büyük güç stratejisinden farklı olarak fikirsel güvenlik anlayışına dayanmaktadır. İkinci Dünya Savaşı sonrasında ABD tarafından kurulan liberal ekonomik düzende tasma kayması, devletlerin "yırtıcı bir toprak avcısı" tarafından saldırıya uğrama korkusundan çok "bağımsız bir dış politika yürütme" arzusu ile ilgili olmuştur. ${ }^{12}$ Bu süreçte sistemin değişimi ABD'nin savunucusu olduğu kurallara uymasına ve yönetimine ikna edici bir alternatif ortaya çıkmasına bağlı olmuştur.

\footnotetext{
${ }_{9}^{9}$ Amitav Acharya, Whose Ideas Matter? Agency and Power in Asian Regionalism, Cornell University Press, Ithaca, 2010, s. 35.

${ }^{10}$ Robert Cox, "Social Forces, States and World Orders: Beyond International Relations Theory", Milliennium Journal of International Studies, 1981, Say1 10/2, 126-155, s. 128.

11 Layne'in tasma kayması nosyonu yumuşak dengeleme çerçevesine normatif bir bileşen yerleştirmiştir. Kavram hakkında daha detaylı bilgi için bkz. Christopher Layne, a.g.e., s. 17.

${ }^{12}$ Layne, a.g.e., s. 46, 49.
} 
$\mathrm{Bu}$ bakımdan, George W. Bush'un doktrini uluslararası sistem açısından özel bir öneme sahiptir. Bush yönetiminin dış politikada diplomatik müzakere ve küresel yönetişim yerine tek taraflı eylem tercihlerine yönelmesi, ABD'nin uluslararası sistemde temsil ettiği hâkim devlet rolünün zayıflamasına neden olmuştur. ABD'nin savunucusu olduğu değerlere uygun davranmaması bu sürece hız kazandırmıştır. Neoklasik realizm uluslararası sistemdeki hâkim devlet geri dönülemez şekilde saldırgan hale geldiğinde, diğer devletlerin ona eklemlenme ihtimalinin olmadığını vurgulamaktadır. ${ }^{13}$ Nitekim Bush yönetiminde ABD'nin takip ettiği tek taraflı politikalar da beraberinde iç ve diş politikada bir dizi ciddi soruna sebep olmuştur. ${ }^{14}$

ABD'nin liderlik ettiği küresel sistemdeki istikrarsızlığın ilk belirtileri ise 11 Eylül 2001 saldırılarıyla gözlemlenmiştir. ABD gibi bir süper güce karşı uluslararası bir terör ağı olarak tanımlanan El-Kaide tarafından düzenlenen bu saldırılar ile “ABD'nin dokunulmazlığı” algısı yeniden şekillenmiştir. Özellikle küreselleşmenin ekonomik simgesi sayılan New York'taki İkiz Kuleler'e, askerî simgesi sayılan Pentagon'a ve siyasi simgesi sayılan Beyaz Saray'a düzenlenen eş zamanlı saldırılar ABD'nin küresel hâkimiyetine karşı önemli bir meydan okuma olmuştur. Bu saldırıların akabinde Bush yönetimi tarafından başlatılan Afganistan ve Irak savaşları ise başarıya ulaşamamıştır. Tüm bu gelişmeler, ABD'nin maddi ve ahlaki gücünün dünya çapında erimesine neden olmuştur.

11 Eylül dışında 2000'lerin ilk on yılında uluslararası sistemdeki güç dağılımına etki yaratan iki önemli gelişme daha meydana gelmiştir. $\mathrm{Bu}$ gelişmelerden ilki, Rusya'nın 2008 yılında Gürcistan'a askerî müdahalesiyle küresel bir güç olarak uluslararası arenadaki etkinliğini arttırmasıdır. Takip eden yıllarda Rusya, sergilediği askerî güç kapasitesi sayesinde eski Sovyet coğrafyasına ilave olarak Orta Doğu, Doğu Akdeniz, Afrika, Latin Amerika ve Kuzey Kutbu gibi bölgelerde nüfuzunu belirgin biçimde arttırmış ve uluslararası sistemdeki yerini sağlamlaştırmıştır. ${ }^{15}$

13 Colin Dueck, Neoclassical Realism and the National Interest: Presidents, Domestic Politics, and Major Military Interventions, Cambridge University Press, Cambridge, 2009, s. $149,151$.

${ }^{14}$ Jason Davidson, America's Allies and War, Palgrave Macmillan, Basingstoke, 2011, s. 34.

${ }^{15}$ Steven Hook and John Spainer, American Foreign Policy since World War II, CQ Press, 
Uluslararası sistemdeki güç dağılımına etki yaratan ikinci önemli gelişme ise 2008'de hız kazanan küresel ekonomik kriz olmuştur. İlk başta ABD'de taşınmaz malların kredilendirme sisteminde patlak veren ve daha sonra pek çok bankanın iflası ile sonuçlanan bu kriz, kısa sürede ABD'den dünyaya yayılarak küresel bir boyut kazanmıştır. Altın ve petrolün değer kazandığ 1 bu dönemde, Amerikan doları ise diğer para birimlerine karşı oldukça fazla değer kaybetmiştir. ${ }^{16}$ Bu dönemde ayrıca ekonomide arz-talep dengesinin kendiliğinden oluşacağı görüşüne tezat olarak ABD hükümetinin iflas ilan eden bankaların kurtarılmasına yardımcı olması da ekonomide "devlet müdahaleciliğinin" yeniden tartışma konusu haline gelmesine neden olmuştur. 2008 krizi öte yandan ekonomik liberalizmin aslında devlet çıkarlarına ne kadar bağlı olduğunu da ortaya koymuştur. ${ }^{17}$

2008 sonrası dönemde uluslararası sistemdeki bir diğer önemli gelişme ise, gelişmekte olan beş büyük ekonomiden oluşan bir blok olan BRICS'in (Brezilya, Rusya, Hindistan, Çin, Güney Afrika) küresel ekonomik kurumlardaki Batı hâkimiyetine meydan okumasıdır. BRICS ülkeleri özellikle Batı önderliğindeki kurumlara alternatif yaratarak ya da mevcut kurumlarda birbirlerini destekleyerek güçlerini arttırmayı amaçlamışlardır. Ayrıca gelişmekte olan ülkelerin gelişmiş ülkelerin yürüttügü politikalardan olumsuz etkilenmelerini gerekçe göstererek, gelişmekte olan ülkelerin ihtiyaçlarına hizmet edecek bir ekonomik düzeni savunmuşlardır. ${ }^{18}$

Yukarıda değinilen tüm bu unsurlar ve özellikle 11 Eylül saldırıları sonrasında ABD'nin başlattığı “teröre karşı savaş” uluslararası güç dengesinde önemli ölçüde değişime neden olmuştur. Uluslararası düzende Rusya, Çin, Hindistan, Brezilya, Türkiye ve İran gibi güçlerin daha aktif hale gelmesi de bu açıdan önemlidir. ${ }^{19}$

\footnotetext{
Washington, 2009, s. 68, 73.

${ }^{16}$ Hook and Spainer, a.g.e., s. $73,82$.

${ }^{17}$ Frédéric Gonthier and Toby Matthews, "The Rise of Interventionism in the European Union and its Social Foundations: An Analysis of Economic Attitudes between 1990 and 2008", Revue Française De Sociologie (English Edition), 2015, Sayı 56/1, 1-38, s. 23.

${ }^{18}$ Rachel S. Salzman, Russia, BRICS, and the Disruption of Global Order, Georgetown University Press, Washington, 2019, s. 97.

${ }^{19}$ Stephen M. Walt, “Alliances in a Unipolar World”, World Politics, 2009, Say1 61/1, 86-120, s. $97,99$.
} 
Schweller'ın belirttiği gibi, tüm yükselen güçler tehlikeli olmasa da revizyonist eğilimlere sahiptirler. ${ }^{20}$ Örneğin yükselen güçler Batılı devletlerin egemen olduğu BMGK gibi uluslararası siyasal kurumlarda ve IMF ile Dünya Bankası gibi uluslararası finansal kurumlarda eşit temsil talep etmektedirler. ${ }^{21}$ Öte yandan 2000 yılından bu yana, yükselen güçlerin neredeyse tamamında istikrarlı bir sosyal ve ekonomik kalkınma görülmektedir. Bu bakımdan, yükselen güçlerin kurdukları yeni siyasi ilişkilerin ve uyguladıkları yeni güvenlik politikalarının uluslararası sistemi değiştirebilecek bir potansiyel taşıdığı iddia edilebilir. Nitekim

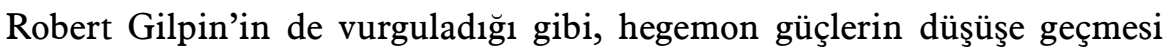
sonrasında güç hiyerarşisinde yeniden bir değişim meydana gelmektedir. Böylelikle, "güç" sistemde yeniden dağıtılmaktadır. ${ }^{22}$

Bu bağlamda, 2009-2017 döneminde uluslararası sistemdeki güç dengelerinde ne gibi değişimler meydana geldiğinin araştırıldığ makale üç bölümden oluşmaktadır. Uluslararası sistemdeki tek kutupluluğun dönüşüm süreci küresel ekonomik krizin yansımaları, Çin'in küresel aktör olarak yükselişi ve Rusya'nın küresel nüfuzunun belirginleşmesi bağlamında ele alınmaktadır.

\section{Küresel Ekonomik Krizin Yansımaları}

2007 yılında ABD emlak piyasasında yaşanan çalkantılarla başlayan ve 5 Eylül 2008'de ünlü Lehman Brothers yatırım bankasının çöküşüyle uluslararası bir bankacılık bunalımına dönüşen küresel ekonomik kriz, 1930'larda yaşanan "Büyük Buhran" döneminden bu yana meydana gelen en ciddi finansal kriz olarak değerlendirilmektedir. İşletmelere fon sağlayamayan bankaların ve borç ödemekte güçlük çeken emlak sahiplerinin yaşadığ finansal problemler, ABD'de Aralık 2007'de başlayan ve Haziran 2009'a kadar süren "Büyük Durgunluk" ile sonuçlanmıştır. Finansal krizin yarattığı sıkıntı devlet müdahalesi ile aşılmaya çalışılmıştır. Bu durum ise

\footnotetext{
${ }^{20}$ Randall Schweller, "Rising Powers and Revisionism in Emerging International Orders", Valdai Paper, Say1 16, 2015, s. 11.

${ }^{21}$ Konu hakkında daha detaylı bilgi için Justin Morris and Nicholas J. Wheeler, "The Security Council's Crisis of Legitimacy and the Use of Force", International Politics, 2007, Say1 44/2, 214-231, s. 220.

22 Robert Gilpin, Global Political Economy: Understanding the International Economic Order, Princeton University Press, Princeton, 2001, s. 106.
} 
ABD'nin yıllardır savunucusu olduğu neoliberal politikaların başarısızlığını gözler önüne sermiştir. ${ }^{23}$

Yaşanan finansal kriz ve iktisadi durgunluk Amerikan ekonomisini çöküşün eşiğine getirirken, ABD ile ekonomik karşılıklı bağımlılı̆̆ 1 yüksek olan $\mathrm{AB}$ bölgesini de derinden sarsmıştır. Denetimsiz bütçe açı̆̆ 1 ve aksayan mali ödemeler nedeniyle Euro bölgesi bu krizden en ileri seviyede etkilenmiştir. İlk olarak 1 Ocak 1999 yllında ekonomik bütünleşmenin bir parçası olarak AB'nin 17 üyesi ortak para birimi "Euro"nun kullanımına geçmiştir. 2007 yılında Bulgaristan ve Romanya'nın katılımı ile üye sayısını 27’ye yükselten $\mathrm{AB}$, küresel krizin yaşandığı dönemden önce çeşitli bütünleşme ve derinleşme sorunları karşı karşıya kalmıştır. ${ }^{24} 2008$ yılında hız kazanan ekonomik kriz ile birlikte ise Portekiz, İspanya, İtalya, Yunanistan ve İspanya'dan oluşan "PİIGS" grubunun kötüleşen mali durumu nedeniyle birliğin mevcut problemleri daha da derinleşmiştir. ${ }^{25}$

Bu nedenle 2010 yılında $\mathrm{AB}$, ekonomik problemlerin çözülmesi adına büyük çaplı kurtarma paketleri oluşturmuştur. AB'nin ekonomik olarak en güçlü üyesi Almanya, bu girişimler aracılığıyla sadece borçlu devletleri değil, ayrıca AB'nin 27 üyesinin 17'si tarafından paylaşılan ortak para birimi Euro'nun prestijini kurtarmak adına ihtiyaç duyulan mali yardımın önemli bir bölümüne destek sağlamıştır. ${ }^{26}$ Öte yandan Fransız Cumhurbaşkanı Nicolas Sarkozy ve Alman Şansölyesi Angela Merkel borçlu devletlerin kendi bütçeleri üzerindeki yetkilerini kısıtlamak istemişlerdir. Ancak özellikle Yunanistan hükümeti bu talepleri reddetmiştir. Buna rağmen 2012 yılında ekonomik krizdeki üye devletler, hazırlanan basska bir kurtarma paketi

\footnotetext{
${ }^{23}$ Hamid Shomali and Gwendolyn Giblin, "The Great Depression and the 2007-2009 Recession: The First Two Years Compared", International Research Journal of Finance and Economics, 2010, Say1 59, 15-22, s. 19.

${ }^{24}$ John Goddard, Philip Molyneux and John Wilson, "The Financial Crisis in Europe: Evolution, Policy Responses and Lessons for the Future", Journal of Financial Regulation and Compliance, 2009, Say1 17, 362-380, s. 362.

25 Terim, 1990'larda AB ekonomilerinin artan entegrasyonu ile ortaya çıkmış ve sıklıkla Güney Avrupa ülkelerinin artan borçları ve ekonomik kırılganlıkları nedeniyle kullanılmıştır. 2008 yılında yaşanan ekonomik kriz ile beraber terim yeniden popüler hale gelmiştir.

${ }^{26}$ John Goddard, "The Financial Crisis in Europe: Evolution, Policy Responses and Lessons for the Future", Journal of Financial Regulation and Compliance, 2009, Say1 17, 362-380, s. 367.
} 
karşıllı̆ında mali ve parasal politikalarda egemenliklerini $\mathrm{AB}$ ile paylaşmayı kabul etmişlerdir. ${ }^{27}$

Batı finansal sisteminin en önemli temsilcileri olan $A B D, A B$ ve Japonya 2008 krizinde finansal olarak en büyük zararı görmüşlerdir. ${ }^{28}$ Örneğin, sadece 2009 yılında ylllık sanayi üretimi ABD'de \%13, Japonya'da \%38, Almanya'da \%29 ve İngiltere'de \%13 düşmüştür. ${ }^{29}$ Japonya borsalarının toplam değeri ise neredeyse $\% 75$ azalmıştır. ${ }^{30}$ Bütçe açı̆̆1 ve ulusal borcu kontrol altına almakta zorlanan $A B D$ ve $A B$ ise ekonomik karş1lıklı bağımlılığı güçlendirmek amacıyla 2013 yılında Transatlantik Ticaret ve Yatırım Ortaklığ (TTIP) müzakerelerini başlatarak karşılıklı ticareti ve çok taraflı ekonomik büyümeyi teşvik etmeyi amaçlamışlardır. Ancak, bu girişim 2016 yılı itibariyle sonuçsuz kalmıştır. ${ }^{31}$

Ekonomik krizin neden olduğu finansal durgunluk dünyada eşit olarak hissedilmemiştir. Gelişmiş ülke ekonomilerini barındıran Kuzey Amerika ve Batı Avrupa'da ciddi bir durgunluk yaşanırken, 2000'ler boyunca önemli ölçüde büyüme gösteren Çin ve Hindistan'da krizin etkileri daha az hissedilmiştir. Nitekim krizin derinleştiği 2009 yllında BRIC ülkeleri ilk zirve toplantısında bir araya gelmiş ve bu tarihten itibaren her sene düzenli olarak toplantılar gerçekleştirmeye başlamışlardır. 2010 yılında ise Çin'in önerisiyle Güney Afrika da BRIC grubuna katılmışır. ${ }^{32}$ 2008-2020 yılları arasında BRICS grubunun dünya ekonomisindeki payı büyük ölçüde artarken, $A B D, A B$, İngiltere ve Japonya'nın payı ise göreceli olarak azalmıştır (Şekil 1 ve Şekil 2).

\footnotetext{
27 "The Commission's Intervention in the Greek Financial Crisis", Europa, https://op.europa.eu/ webpub/eca/special-reports/greek-crisis-17-2017/en/ (Erişim Tarihi: 28.05.2020)

${ }^{28}$ Samir Amin, Beyond US Hegemony? Assessing the Prospects for a Multipolar World, Zed Books, New York, 2006, s. 87.

${ }^{29}$ Germain Randall, "Financial Order and World Politics: Crisis, Change and Continuity", International Affairs, 2009, Say1 85/4, 669-687, s. 680.

${ }^{30}$ Simon Serfaty, "Moving Into A Post-Western World", The Washington Quarterly, 2011, Sayı 34/2, 7-23, s. 19.

31 "EU Negotiating Texts In TTIP", Europa, https://trade.ec.europa.eu/doclib/press/ index.cfm?id=1230 (Erişim Tarihi: 30.05 .2020 )

32 Ram Prasad Bandi, "BRICS: International Financial Crisis and Challenges of Governance", Conference: International Symposium on Building Governance Systems and Capabilities of BRICS Countries, 2014, 2-20, s. 18.
} 


\section{Şekil 1: 2008 Yılında Dünya Ekonomisi ${ }^{33}$}

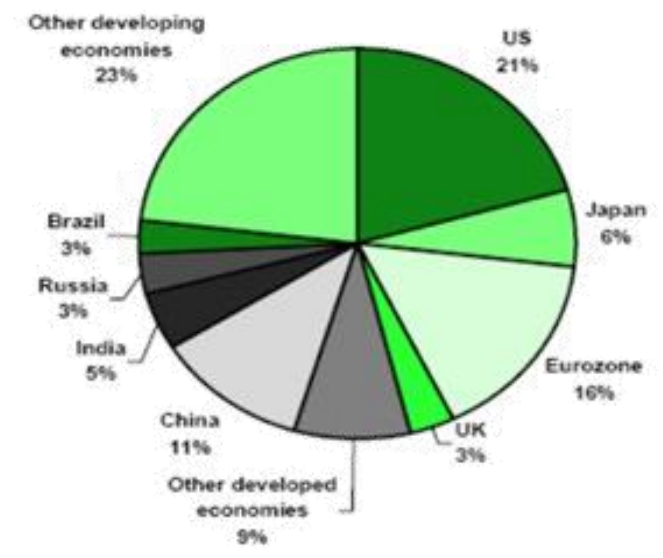

\section{Şekil 2: 2020 Yılında Dünya Ekonomisi ${ }^{34}$}

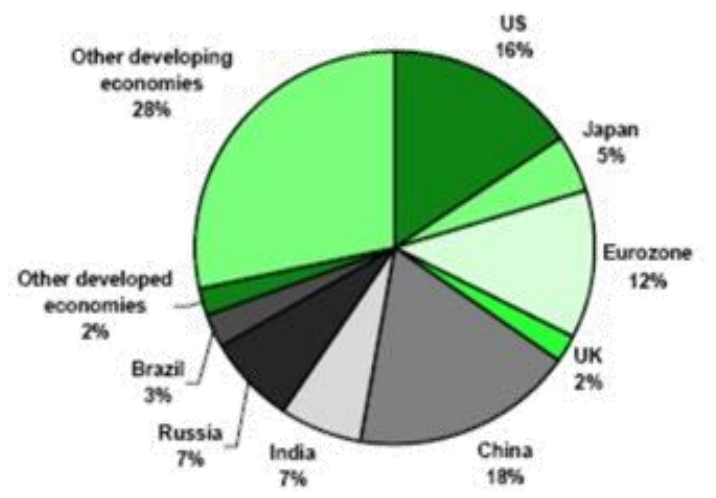

33 "World Economic Outlook Database-PPP Adjusted GDP Shares", IMF, Report for Selected Countries and Subjects (imf.org) https://www.imf.org/en/Publications/WEO/weodatabase/2020/October/weo-report?c=513,514,516 (Erişim Tarihi: 01.01.2021)

${ }^{34}$ World Economic Outlook Database-PPP Adjusted GDP Shares, $I M F$, Report for Selected Countries and Subjects (imf.org), https://www.imf.org/en/Publications/WEO/weo-database/ 2020/October/weo-report?c=513,514,516 (Erişim Tarihi: 01.01.2021) 
2008 krizi AB'nin derinleşmeye yönelik politikalarını da önemli ölçüde sekteye uğratmış, birliğin etkinliğinin sorgulanmasına yol açmış ve pek çok üye ülkede yapılan genel seçimlerin sonuçlarını şekillendirmiştir. ${ }^{35}$ Benzer şekilde, ABD'de 2008 yılında gerçekleşen seçimlerde de ekonomik sıkıntıların en önemli belirleyici unsur olduğu görülmektedir. ${ }^{36}$ Böyle bir ortamda yönetime gelen Obama dış politikada Bush'un tek taraflı politika tercihlerini reddederek çok taraflılığ , uluslararası kurumlarla iş birliğini ve küresel diplomasiyi önceleyen bir yaklaşım benimsemiştir.

Finansal kriz, Çin ve diğer Asya ekonomileri üzerinde ise göreceli olarak daha az sarsıcı etkiler oluşturmuştur. Bu durum da uluslararası ilişkiler açısından "Doğu'nun yükselişi” ${ }^{37}$ tartışmalarını güçlendirmiştir. Örneğin Parag Khanna dünyanın Asya, ABD ve Avrupa tarafından yönetilen en azından üç kutuplu bir sisteme doğru evrildiğini belirtirken, Fareed Zakaria ve Kishore Mahbubani gibi yazarlar uluslararası sistemin artık Batı ülkelerinin hâkimiyeti altında olmadığına dikkat çekmişlerdir. Tüm bu tartışmalarda özellikle Çin'in küresel bir aktör olarak oynadığı rolün önemine vurgu yapıldığ 1 görülmektedir.

\section{2. Çin'in Küresel Aktör Olarak Yükselişi}

Soğuk Savaş sonrasında Asya'nın hâkim gücü olarak görülen Çin'in uyguladığı otoriter siyasi model Batılı liberal demokrasi modeline meydan okumuş, benzer biçimde Çin'in takip ettiği müdahaleci ekonomik model de ABD'nin serbest piyasa modeline alternatif olarak görülmüştür. Çin Komünist Partisi'nin tek parti olarak faaliyet gösterdiği Çin'de sanayi 1980'lerden itibaren özelleştirilmiş ve takip eden yıllarda bankalar yabancı yatırımlarla dolarken çalışanlar iş piyasasında serbest kalmışlardır. Ancak ekonomik alandaki bu değişime rağmen Çin Komünist Partisi iktidardaki tekelinden vazgeçmemiş ve bu konuda herhangi bir değişim yaşanmasına izin vermemiştir. Günümüzde Çin'in özellikle siyasi şeffaflık alanında

35 Liisa Talving, "Economic Voting in Europe: Did the Crisis Matter?", Comparative European Politics, 2017, Say1 10, 1-30, s. 28.

36 Pedro Magalhães, "Financial Crisis, Austerity, and Electoral Politics", Journal of Elections Public Opinion \& Parties, 2014, Say1 24, 125-133, s. 132.

37 Parag Khanna, The Future Is Asian: Global Order in the Twenty-first Century, Weidenfeld \& Nicolson, London, 2019; Kishore Mahbubani, "The Not-So-Surprising Rise of China and India”, Journal of International Affairs, 2011, Say1 64/2, 221-226, s. 225. 
ciddi sorunları olsa da ülkedeki mahkemelerin yine de belli bir ölçüde hukukun üstünlügüne göre hareket ettiği ifade edilmektedir. ${ }^{38}$

2008 yılında meydana gelen küresel krizin etkilerine rağmen ekonomik gelişmesine devam eden Çin, bu dönemde dahi önceden açıllamış olduğu kalkınma planlarına kademeli olarak devam etmiştir. Nitekim neoklasik realizmin önde gelen isimleri arasında yer alan Zakaria Newsweek'de kaleme aldığ "How to Deal with China" başlıklı makalesinde kriz döneminde Çin'in büyümeye devam ettiğinin özellikle altını çizmiştir. Zakaria Çin'in yatırımlarını günlük harcamalar yerine geleceğe dönük projelere yönlendirdiğini vurgulamıştır. ABD'nin 2008 krizinden diğer ülkelere kıyasla neden daha çok etkilendiğine değinen Zakaria, bu durumu ABD serbest piyasasında görülen düşük enflasyon ve yüksek miktarda nakit paranın faiz oranlarını düşürmesi ve harcama dengesini etkilemesi olarak açıklamıştır. Zakaria Çin'in ise ekonomik krizde sarsıntı yaşayan çoğu ülkenin aksine para akışını kısıtladığına ve harcamalarını alt yapı, büyüme ve yeni teknolojiye yönlendirdiğine dikkat çekerek, bu politikanın Çin'in başarısının ardında yatan temel neden olduğunu belirtmiştir. ${ }^{39}$

Çin'in küresel aktör olarak yükselişi konusuna "The Rise of The Rest" başlıklı bir diğer makalesinde detaylı olarak yer veren Zakaria, 21. yüzyılın başındaki en önemli uluslararası olayın "diğer ülkelerin yükselişi” olduğunu belirtmiştir. ${ }^{40}$ Zakaria'ya benzer şekilde Acharya da ABD'nin II. Dünya Savaşı'ndan sonra inşa ettiği uluslararası düzenin erozyonuna atıfta bulunarak ABD'nin küresel liderlik rolünün zayıfladığına dikkat çekmiştir. Acharya, özellikle ABD'nin kurulmasına yardımcı olduğu küresel ve çok taraflı kurumların gündemini şekillendirmekte ve kontrol etmekte giderek daha

\footnotetext{
38 "2020 Country Brief: China", Third Way, 2020, www.jstor.org/stable/resrep26161 (Erişim Tarihi: 05.05.2020)

39 Fareed Zakaria, "How to Deal with China", Newsweek, https://www.newsweek.com/ fareed-zakaria-how-handle-china-87711 (Erișim Tarihi: 03.06.2020)

${ }^{40}$ Zakaria, ABD'nin yeni dünyaya liderlik etme yeteneğindeki şüpheli konumunu tartıştı̆̆ "The Rise of The Rest" adlı eserinde, dünyanın dört bir yanındaki güç ve tutumların değiştiğini kanıtlayan birçok örneği tartışmış, diğer ülkelerin bir zamanlar Amerikancılık karşıtı olduğunu, ancak şimdi dünyanın post-Amerikancılık durumuna evrildiğini belirtmiştir. Zakaria, bu nedenle sorunun temelde ABD'nin zayıflaması değil ancak ABD dışındaki milyarlarca insan ve gücün her alanda ABD'ye yetişmesi ve hatta geçmesi olduğunu belirtmiş̧ir. Daha fazla bilgi için bkz. Fareed Zakaria, "The Rise of The Rest". Newsweek. May 2008, https://fareedzakaria.com/ columns/2008/05/12/the-rise-of-the-rest (Erişim Tarihi: 03.05.2020)
} 
başarısız hale geldiğini iddia etmiştir. Ayrıca günümüzde uluslararası düzenle ilgili asıl sorunun ABD'nin gerilemesi ile ilgili olmadığını belirtirken, temel problemin Amerikan dünya düzeninin sona ermesi olduğunu iddia etmiştir. ${ }^{41}$

Acharya öte yandan Batı'da liberal demokrasinin aşınmasının sadece liberal ideolojinin değil, liberal uluslararası düzenin de gerilemesine işaret ettiğini ifade etmiştir. ${ }^{42}$ Robert Keohane'nin "uluslararası düzende tek bir hegemon gücün varlığı yeterli değildir" tespitine katılan Acharya, karşılıklı bağımlılığın artması ile birlikte liberal hegemonya döneminin geçmişte kaldığını ileri sürmüştür. ${ }^{43}$ Dünya düzeninin çok kutupluluk olarak tanımlanmasını da eleştiren yazar, bunun yerine mevcut küresel düzenin çok aktörlü ve çok boyutlu olduğuna dikkat çekmiştir. Bu nedenle uluslararası sistemi çok düzeyli diğer deyişle "multiplex" bir dünya düzeni olarak tanımlamıştır. ${ }^{44}$ Acharya'a göre Çin'in olağanüstü ekonomik büyümesi küresel serbest ticaretin genişlemesinin arkasında yatan en temel faktör olmuştur. Bu nedenle yeni küreselleşme eğiliminin itici gücünün Batı değil, Çin olduğunu belirtmiştir. Bu bağlamda Acharya, özellikle Çin'in "Kuşak ve Yol (The Belt and Road Initiative)" adını verdiği girişimine dikkat çekmiştir. ${ }^{45}$

İlk başta "Tek Kuşak, Tek Yol (One Belt One Road)" olarak ilan edilen ancak 2016 yılında Kuşak ve Yol Girişimi (KYG) adını alan proje, krizden başarıyla çıkan Çin'in küresel ölçekte artan özgüveninin bir göstergesi olarak görülebilir. Çin hükümeti tarafından 2013 yılında ilan edilen bu proje, dünyanın son dönemdeki en büyük kalkınma projeleri arasında gösterilmektedir. Asya, Avrupa ve Afrika'daki yaklaşık 70 ülkede altyapı yatırımlarını merkeze alan proje kapsamında belirtilen "kuşak" kavramı karayolu ve demiryolu taşımacılığını, "yol" ise deniz yolu taşımacılığını ifade etmektedir. KYG'nin Çin'nin kuruluşunun 100. yıldönümü olan 2049 yılında tamamlanması hedeflenmektedir. ${ }^{46}$

\footnotetext{
${ }^{41}$ Amitav Acharya, The End of American World Order, Polity, Cambridge, 2018, 19-27, s. 25.

${ }^{42}$ Amitav Acharya, "After Liberal Hegemony: The Advent of a Multiplex World Order”, Ethics \& International Affairs, 2017, Say1 31/3, 271-285, s. 282.

${ }^{43}$ Robert O. Keohane, After Hegemony: Cooperation and Discord in the World Political Economy, Princeton University Press, Princeton, 1984, s. 46.

${ }^{44}$ Acharya, a.g.e., s. 271.

${ }^{45}$ Acharya, a.g.e., s. 278, 279.

${ }^{46}$ Yuen Yuen Ang, "Demystifying Belt and Road the Struggle to Define China's "Project of the Century", Forreign Affairs. 2019, https://www.foreignaffairs.com/articles/china/ 2019-
} 
Günümüzde Avrupa'nın liman kapasitesinin \%10'unu kontrol eden Çin'in, KYG'nin ana parçalarından birisi olan "Deniz İpek Yolu" projesinin hedeflerine uygun olarak ilerlediği görülmektedir. ${ }^{47}$ Buna ek olarak, KYG kapsamında ilgili ülkelerdeki kritik altyapıların tesis edilmesi alanında da faaliyet gösteren Çin, özellikle 5G iletişim sistemlerinin kuruluşuna öncülük etmeye çalışmaktadır. Böylelikle Çin'in oldukça geniş bir coğrafyada özel, kamusal, ticari ve askerî iletişim ağlarına erişim üstünlüğüne sahip olması planlanmaktadır. ${ }^{48}$

2050 y1lına kadar bilim ve inovasyon alanında dünya lideri haline gelinmesi de Çin'in kalkınma planları arasında yer almaktadır. ${ }^{49}$ Bu kapsamda, 2015 yllında "Made in China 2025" projesi ilan edilmiştir. Bu proje ile Çin, düşük işçilik maliyetleri ve tedarik zinciri avantajları nedeniyle ucuz ve düşük kaliteli ürünler üreten bir "dünya fabrikası" olmaktan öteye geçmeyi hedeflemektedir. ${ }^{50}$ Dolayısıyla havacılık hizmetleri ve yarı iletkenlerin üretimi gibi alanlarda öne geçmeyi ve bu alanlarda yabancı tedarikçilere olan bağımlılı̆̆ı azaltmaya çalışmaktadır. Proje hedefleri arasında Çin'deki yerli üretimin 2020 yılına kadar \%40'a ve 2025'e kadar \%70'e çıkarılması da yer almaktadır. ${ }^{51}$ Ayrıca robotlar ve tıbbi cihazlar gibi yüksek teknoloji ürünleri endüstrisinde Çin'in lider konuma gelmesi amaçlanmaktadır.

Çin ayrıca 2035 yılına kadar silahlı kuvvetlerini tamamen modernize etmeyi ve 2050 yılına kadar tam teşekküllü bir üst düzey orduya sahip olmayı hedeflemektedir. Öte yandan silah satışı alanında giderek daha etkin

05-22/demystifying-belt-and-road (Erişim Tarihi: 06.05.2020)

${ }^{47}$ Keith Johnson, "Why Is China Buying up Europe's Ports?", Foreign Policy Report, 2018, https://foreignpolicy.com/2018/02/02/why-is-china-buying-up-europes-ports/ (Erişim Tarihi: 07.05.2020)

${ }^{48}$ Katie Benner, "China's Dominance of 5G Networks Puts U.S. Economic Future at Stake, Barr Warns", NY Times, "https://www.nytimes.com/2020/02/06/us/politics/barr-5g.html (Erişim Tarihi: 07.05.2020)

${ }^{49}$ Lindsay Gallowey, "Five Superpowers Rulling the World in 2020", BBC News, March 2020, http://www.bbc.com/travel/story/20200322-five-superpowers-ruling-the-world-in-2050 (Erişim Tarihi: 07.05.2020)

50 Ma Huimin, "Strategic Plan of "Made in China 2025" and its Implementation", IGI Global, 2018, 1-23, s. 18.

51 James McBride and Andrew Chatzky, "Is 'Made in China 2025' a Threat to Global Trade?", Council on Foreign Relations. May 2019. https://www.cfr.org/backgrounder/ made-china-2025-threat-global (Erişim Tarihi: 03.07.2020) 
hale gelen ülkenin, yakın gelecekte gelişmiş silah sistemleri de ihraç edebilecek kapasiteye ulaşması beklenmektedir. Bu durum, Çin'in daha geniş bir coğrafyada nüfuz gösterebilmesine de olanak sağlayacaktır. ${ }^{52}$

Tüm bu gelişmeler 1şı̆̆ında Çin'in Batı'nın askerî ve teknolojik üstünlügüne artan düzeyde meydan okuduğu ifade edilebilir. Nitekim $\mathrm{AB}$ bünyesinde yapılan çalışmalarda Çin'in 2030 yılına kadar dünyanın en güçlü ordusuna sahip ülkeler arasında ilk beşte yer alacağı iddia edilmektedir. ${ }^{53}$

Küresel siyasette de nüfuz alanını genişletmek isteyen Çin, ABD hegemonyasında kurulan örgütlere alternatif oluşturmak üzere önemli adımlar atmıştır. Bu adımlardan en önemlisi Şanghay İşbirliği Örgütü’dür (ŞİÖ). ${ }^{54}$ ŞïÖ 15 Haziran 2001'de Çin, Kazakistan, Kırgızistan, Rusya, Tacikistan ve Özbekistan liderleri tarafindan Şanghay'da kurulmuştur. Bir siyasi, ekonomik ve güvenlik ittifakı olarak oluşturulmuş olan bu örgüt, 19 Eylül 2003 tarihinde resmî faaliyetlerine başlamıştır. Hindistan ve Pakistan'ın 9 Haziran 2017 tarihinde Kazakistan'ın Astana kentinde yapılan zirvede ŞIOÖye tam üye olarak katılması ile birlikte üye sayısı sekize çıkmıştır. ŞİÖ üye ülkelerinin dünya nüfusunun yaklaşık yarısını, dünya Gayrisafi Yurt İçi Hasıla'sının (GSYH) dörtte birini ve Avrasya bölgesinin yaklaşık \%80'ini oluşturmaktadır. ${ }^{55}$ Geniş bir coğrafyayı temsil etmesi nedeniyle ŞïÖ aynı zamanda "Doğu İttifakı" olarak da kabul edilmektedir. ${ }^{56}$

Neoklasik realizm ittifakların yalnızca ortak çıkarlara dayalı anlaşmalar ve resmî düzenlemeler olarak kurulabileceğini ve açık bir askerî destek

\footnotetext{
52 Derek Adam Levine, "Made In China 2025: China's Strategy for Becoming a Global HighTech Superpower and its Implications for the U.S. Economy, National Security, and Free Trade", Journal of Strategic Security, 2020, Sayı 13/3, 1-16, s. 14.

53 "Shifting Balance of Power", Europa, 2020, https://ec.europa.eu/knowledge4policy/ foresight/topic/changing-security-paradigm/changing-nature-balance-power (Erişim Tarihi: 19.09.2020)

54 Üye devletler arasında siyasi, ekonomik, ticari ve bilimsel alanlarda etkin iş birliği sağlayarak teknoloji, kültür, eğitim, enerji, iletişim, çevre ve diğer alanlarda kendilerini bölgesel barışı korumaya adayan ŞïÖ, güvenlik ve istikrar temelli demokratik, adil ve rasyonel yeni bir uluslararası siyasi ve ekonomik düzen kurmayı hedeflemiştir.

${ }^{55}$ Paul Stronski and Richard Sokolsky, "SCO: Multipolarity in Practice: Understanding Russia's Engagement with Regional Institutions", Carnegie Endowment for International Peace Report, 2020, 11-18, s. 17.

56 "SCO Explores Global Governance for New Era", Global Times, http://www.globaltimes.cn/content/1106373.shtml (Erişim Tarihi: 19.09.2020)
} 
taahhüdüne gerek olmadığını ileri sürmektedir. ${ }^{57}$ Ticaret ve güvenlik ilişkilerinin iyileştirilmesi gibi karşılıklı çıkarlara ulaşmak için kurulan anlaşmalar ise stratejik ortaklıklar olarak tanımlanmaktadır. ${ }^{58} \mathrm{Bu}$ nedenle, neoklasik realizm açısından ele alındığında Rusya ile Çin arasında kurulan stratejik ortaklık, yumuşak dengelemeye örnek olarak gösterilebilir. ${ }^{59}$

Jeopolitik açıdan, stratejik ortaklıklar devletlerin uluslararası kurum veya bölgesel örgütlerde bir araya gelerek güçlerini birleştirmesi ve "iki birden iyidir" yaklaşımını benimsemesidir. ${ }^{60}$ Böylelikle stratejik ortaklar diğer devletlere oluşturdukları yeni örgütlere üyelik seçeneği sunarak hegemonun etkisini azaltabilmektedirler. Bu bakımdan statükodan memnun olmayan zayıf devletler veya yükselen güçler stratejik ortaklıklar kurarak uluslararası politikadaki etkilerini büyük ölçüde artırabilmektedirler. ${ }^{61} \mathrm{Bu}$ açıdan değerlendirildiğinde Rusya ve Çin'in ŞiÖ’yü kurarak yaptıkları iş birliği, aralarındaki ilişkiye Orta Asya özelinde bölgesel bir boyut da kazandırmıştır. $\mathrm{Bu}$ şekilde Rusya-Çin ilişkilerinin stratejik boyutu da güçlenmiştir.

Şi̇Ö'nün kuruluşu bir anlamda Rusya'nın tek bir kutbun hâkim olduğu dünya düzenine meydan okuma politikasının ilk adımı olarak da ifade edilebilir. ${ }^{62}$ Nitekim 2007 y1lında düzenlenen ŞïÖ Bişkek Zirvesi'nde Devlet Başkanı Vladimir Putin'in "tek kutuplu dünya kabul edilemez" açıklaması da Rusya'nın bu hedefini ortaya koymaktadır. ${ }^{63}$ Özellikle Orta Asya'daki Amerikan nüfuzuna karşı koymayı amaçlayan örgüt, 2005 yılında düzenlenen zirveye Amerikalı gözlemcilerin katılma talebini reddetmiştir. Ayrıca Avrupa Güvenlik ve İşbirliği Teşkilatı (AGİT) kapsamında Amerikalı

\footnotetext{
57 Randall L. Schweller, "New Realist Research on Alliances: Refining, not Refuting, Waltz's Balancing Proposition”. The American Political Science Review. 1997, Say1 91/4, 927-930, s. 928.

${ }^{58}$ Walt, a.g.e., 1987 , s. 68.

${ }^{59}$ William Wohlforth, "Russia's Soft Balancing Act", Strategic Asia Fragility and Crisis, 2003, Say1 4, 165-179, s. 173.

${ }^{60}$ Thomas Ambrosio, "Catching the 'Shanghai Spirit': How the Shanghai Cooperation Organization Promotes Authoritarian Norms in Central Asia", Europe-Asia Studies, 2008, Say1 60/8, 1321-1344, s. 1336.

${ }^{61}$ Stephen M. Walt, The Origins of Alliance, Cornell University Press, NY, 1987, s. 136.

${ }^{62}$ Sangtu Ko, "Strategic Partnership in a Unipolar System: The Sino-Russian Relationship", Issues \& Studies, 2006, Say1 42/3, 203-225, s. 219.

63 "Putin: Unipolar World Unacceptable to Russia", Republica, https://www.republika. co.id/amp_version/njfzxy (Erişim Tarihi:11.12.2020)
} 
2009-2017 Arası Küresel Sistemin Güvenlik Dönüşümü:

Tek Kutupluluk Çok Kutupluluğa Karş1

yetkililerden ve sivil toplum kuruluşlarından (STK) ŞİÖ üyelerine yönelik yapılan eleştirilere bir yanıt olarak kendi seçim gözlemcileri kadrosunu kurmuştur. Bu açıdan ŞïÖ, Batı'nın demokratikleşme ve insan hakları kavramlarına bir alternatif olarak "egemen demokrasi" kavramını öne çıkarmaktadır. ${ }^{64}$

BRICS'in küresel ekonomik düzende Batı hâkimiyetine meydan okumak için kuruluşu da Çin'in Batı önderliğindeki kurumlara alternatif yaratma politikası ile uyumludur. ${ }^{65} 2001$ yılında BRIC ülkelerinin küresel GSYİH içindeki payı \%17 civarındayken, 2011 yılında (2008 yılındaki ekonomik krize rağmen) bu oran \%25'e yükselmiştir. Bu artıs BRICS'in uluslararası ekonomik dengelerin dönüşümünde üstlendiği rolün önemli bir göstergesi olmuştur. ${ }^{66}$ BRICS ayrıca her yıl düzenlediği zirvelerin sonunda yayınladığı bildirilerde gelişmekte olan ülkelerin BM, Dünya Bankası ve IMF'deki temsil güçlerinin artırılması için de demokratik reformlar talep edilmektedir. Öte yandan BRICS ülkeleri, gelişmekte olan ülkelerin DTÖ'deki etkisini artırarak küresel ekonomideki güç dengesinin değiştirilmesinde önemli rol oynamaktadırlar. ${ }^{67}$

BRICS'in kuruluşunun yanı sıra dünyanın ekonomik ekseninin yön değiştirdiği görüşünü güçlendiren bir diğer önemli gelişme de G-20 mekanizmasının etkisini attırmasıdır. ${ }^{68} 1997$ 'de patlak veren Asya krizi

\footnotetext{
${ }^{64}$ Kavram Rus siyasetinde ilk kez 22 Şubat 2006'da Vladislav Surkov tarafindan Rus siyasi partisi Birleşik Rusya'nın bir toplantısından önce yaptığı bir konuşmada kullanılmıştır. Surkov'a göre egemen demokrasi: toplumun siyasi hayatında siyasi güçlerin otoritelerinin ve kararlarının maddi refaha, özgürlüğe ve adalete ulaşmak amacıyla onu oluşturan Rus ulusu tarafindan kararlaştırılması ve kontrol edilmesidir. Terim daha sonra Başbakan Putin tarafından kavramsallaştırılmıştır. Konu hakkında daha detaylı bilgi için bkz. Ivan Krastev, “"Sovereign Democracy' Russian-Style”, Insight Turkey, 2006, Say1 8/4, 113-117, s. 115.

${ }^{65}$ Jyrki Kakönen, "BRICS As A New Power In International Relations?", Geopolitics, History, and International Relations, 2014, Say1 6/2, 85-104, s. 98.

${ }^{66}$ Irina Radulescu, Panait Mirela and Catalin Voica, "BRICS Countries Challenge to the World Economy New Trends", Procedia Economics and Finance, 2014, Say1 8, 604-613, s. 609.

${ }^{67}$ Ramesh Thakur, "How Representative Are BRICS?", Third World Quarterly, 2014, Say1 35/10, 1791-1808, s. 1806.

${ }^{68}$ Dünyanın en büyük ekonomileri arasında yer alan 19 ülke ve Avrupa Birliği Komisyonu'ndan oluşan Maliye Bakanı ve Merkez Bankası Başkanı Grubu. G20 ülkeleri: Almaya, ABD, Arjantin, Avusturalya, Brezilya, Çin, Endonezya, Fransa, Güney Afrika, Güney Kore, Hindistan, İngiltere, İtalya, Japonya, Kanada, Meksika, Rusya, Suudi Arabistan, Türkiye ve AB Komisyonu'ndan oluşmaktadır.
} 
sonrasında küresel finans piyasalarını dengelemek üzere 1999 yılında gelişmiş ve gelişmekte olan ekonomilerin maliye bakanları tarafından ortak bir forum olarak kurulan bu mekanizma son yillarda ekonomik ve siyasi etkisini oldukça arttırmıştır. Nitekim 2008 yılında G-20 toplantıları devlet ve hükümet başkanları zirvelerine dönüşmüştür. 2009 yılındaki Pittsburgh Zirvesi'nde ise G-20, dünya liderleri tarafından uluslararası ekonomik iş birliği için ana forum olarak ilan edilmiştir. ${ }^{69} \mathrm{G}-20$ 'nin bir bakıma G-7'nin yerini alması, Batılı olmayan devletlerin dünya ekonomisinde yükselen etkilerinin önemli bir yansıması olmuştur. Yine aynı zirvede alınan karar ile gelişmekte olan ülkelerin Dünya Bankası'ndaki oylama sistemindeki payları da \%47'ye yaklaşmıştır. ${ }^{70}$

BRICS'in küresel ekonomik örgütlerde, ŞİÖ'nün ise askerî ve siyasal örgütlerde Batı hâkimiyetine karşı yarattığı etkiler, Çin'in küresel aktör olarak yükselişinin uluslararası sistemdeki yansımaları olarak görülebilir. Batılı kurumlara alternatif yaratma misyonu Rusya ve Çin'i ortak paydada buluşturmakta ve ikili ilişkilerinin derinleşmesini sağlamaktadır. ABD'nin öncülük ettiği küresel düzene karşı şekillenen bu kapsamlı stratejik ortaklık ayrıca uluslararası güç dengesinde değişikliğe neden olmaktadır. Bu bağlamda, Rusya da özellikle 2008'den sonra en az Çin kadar önemli bir küresel aktör olarak görülmektedir.

\section{Rusya'nın Küresel Nüfuzunun Belirginleşmesi}

Rusya'nın dış politika ideolojisinde Soğuk Savaş'ın sona ermesinden sonra önemli bir değişim meydana gelmiştir. Sovyetler Birliği’nin dağılmasını takiben kurulan Rusya Federasyonu, karşı karşıya kaldığı sorunlar ve zayıflamış askerî ve ekonomik kapasitesinden kaynaklanan güç zafiyeti nedeniyle özellikle 1990'lar boyunca Amerikan tek kutupluluğuna dayanan yeni dünya düzenini kabul etmek zorunda kalmiştır. ${ }^{71}$

${ }^{69}$ Colin Bradford and Lim Wonhyuk, Global Leadership in Transition: Making the G20 More Effective and Responsive, Brookings Institution Press, 2011, s. 34-38.

${ }^{70}$ Emre Erşen, "Rise of New Centres of Power in Eurasia", Journal of Eurasia Studies, 2014, Say1 5/2, s. 6.

${ }^{71}$ Richard Sakwa, "New Cold War Or Twenty Years Crisis?: Russia and International Politics", International Affairs, 2008, Say1 2, 241-267, s. 245. 
Rusya Federasyonu'nun ilk devlet başkanı olan Boris Yeltsin'in dış politikada temel amacı ülkesinin Batı nezdinde eşit bir ortak olarak tanınması olmuştur. Bu kapsamda, Yeltsin'in özellikle ilk başkanlık döneminde benimsediği “Atlantikçi” yaklaşım Rusya'nın Yeltsin yönetiminin dış politika uygulamalarına yansımıştır. ${ }^{72}$ Rusya bir taraftan kapitalist piyasa ekonomisine hızlı bir geçiş yapmaya çalışırken, diğer taraftan dış politikada Batı ile uyumlu ilişkiler geliştirmeyi amaçlamıştır. Ne var ki ülkede sosyalist ekonomiden kapitalist ekonomiye geçiş süreci son derece sancılı olmuş ve kısa sürede sosyal devletin çöküşü, kronik yoksulluğun yaygınlaşması ve yüksek enflasyonun kalıcı hale gelmesi gibi önemli sorunlar baş göstermiştir. Nitekim 1998 yllında Rusya'da büyük bir ekonomik kriz patlak vermiştir. Ayrıca, "oligarklar" adı verilen bir grup iş adamı bu süreçte ekonomik güçlerini muazzam ölçüde arttırarak medya, telekomünikasyon, enerji, finans gibi alanlarda büyük şirketlerin kontrolünü ele geçirmişlerdir.

Yeltsin yönetimi içeride bu sorunlarla baş etmekte zorlanırken aynı zamanda 1994'te Çeçenistan'ın Rusya Federasyonu'ndan ayrılmasını önlemek için başlattığı savaşta başarılı olamamış ve 1996'da bir ateşkes anlaşması imzalayarak Çeçenistan meselesinin çözümsüz kalmasını kabullenmek zorunda kalmıştır. Dış politikada ise Yeltsin'in tüm çabalarına rağmen NATO’nun eski Doğu Bloğu ülkelerini içine alacak şekilde genişlemesi önlenememiş ve bu nedenle Atlantikçi yaklaşım Rusya'da pek çok kesim tarafından sert eleştirilere maruz kalmıştır. Tüm bu sorunlar sonucunda Yeltsin 1999 yılının son gününde devlet başkanlığından istifa ederek görevini Ağustos 1999'dan beri başbakanlık koltuğunda bulunan Vladimir Putin'e devretme kararı almıştır. ${ }^{73}$

Vladimir Putin iktidara geldikten sonra selefi Yeltsin'in Batı'yla ilişkileri öne çıkaran diş politika yaklaşımını yavaş yavaş terk etmeye başlamıştır. ${ }^{74}$ Putin bu kapsamda Rusya'nın nükleer bir süper güç olmaya

\footnotetext{
${ }^{72}$ Atlantikçilik, Avrupa ve Kuzey Amerika ülkeleri arasında, politika, ekonomi ve savunma konularındaki iş birliğinin önemine vurgu yapan düşünce tarzıdır. Yeltsin dönemi hakkında daha fazla bilgi için bkz. Stephen White, Understanding Russian Politics, Cambridge University Press, Cambridge, 2011, s. 45.

73 Merve İrem Yapıcı, Rus Dış Politikasını Oluşturan İ̧̧ Etkenler: Yeltsin Ve Putin Dönemleri, USAK Yayınları, Ankara, 2010, s. 124.

${ }^{74}$ Emre Erşen, 'Neo-Eurasianism and Putin's 'Multipolarism' in Russian Foreign Policy”,
} 
devam etmesi, uluslararası alanda daha etkin bir ülke haline gelmesi ve özellikle Avrasya coğrafyasında meydana gelen siyasi, askerî ve ekonomik gelişmelerde liderlik rolü oynaması gibi temel hedefleri benimsemiştir. ${ }^{75}$

Putin'in 2000-2008 arasındaki politikalarına pragmatik bir yaklaşımın hâkim olduğunu söylemek mümkündür. İç politikada başlattığı idari reformlarla Rusya'da iktidarın daha merkezî bir hale gelmesini sağlamış ve Çeçenistan'a ikinci kez askerî müdahalede bulunarak Yeltsin yönetiminin çözmekte zorlandığı bu önemli meselede ciddi bir askerî başarı kazanmıştır. Putin ayrıca ekonomi alanında da hızlı adımlar atmıştır. Bu sayede oligarkların ekonomi üzerindeki etkileri belirgin biçimde zayıflatılırken, pek çok büyük şirkette Rus devletinin payının hızla artması sağlanmıştır. Ayrıca Yeltsin döneminde özelleştirmeden elde edilen gelirler doğru yönlendirilemezken, Putin tarafından yürütülen ekonomik reformlar sayesinde yüksek enflasyonun önüne geçilmiş ve maaş seviyeleri ile rublenin satın alma gücü artmıştır. Öte yandan, özellikle vergi alanında önemli düzenlemeler yapılmış ülkedeki vergi sistemi düzenlenerek halktan alınan vergilerde yaklaşık \%12 oranında azalma sağlanmıştır. Tüm bu adımların sonucunda 2007 y1lı verilerine göre 1999'dan itibaren Rusya'da GSYH her y1l yaklaşık \%7 oranında artış göstermiştir. Dolayısıyla, 2000 yılında 2 bin 270 dolar olan kişi başına düşen millî gelir 2002'de 9 bin 700 dolara, 2007 yılında ise yaklaşık 13 bin dolara yükselmiştir. ${ }^{76}$ Yine 2007 yılında Rusya ekonomisinin toplam büyüklügü 1990 yılına oranla yaklaşık olarak altı kat artarak 200 milyar dolardan 1,3 trilyon dolara yükselmiştir. ${ }^{77} \mathrm{Bu}$ dönemde Rusya ayrıca gelişmekte olan ülkeler arasında ekonomisine doğrudan yabancı yatırım yapılan ülkeler arasında da ilk sıraya yükselmiştir. Bu şekilde hızla dış borçlarını kapatan ülkede, altın rezervleri 400 tona ve döviz rezervleri 280 milyar dolara ulaşmışır. ${ }^{78} \mathrm{Bu}$ ekonomik toparlanmada 2000'ler boyunca yüksek seyreden petrol fiyatlarının da rolü büyük olmuştur.

\footnotetext{
Turkish Rewiew of Euroasian Studies, 2004, Say1 4, 135-172, s. 145, 147.

75 Nicholas Rose Smith, "Assessing the Trajectory of West-Russia Relations in Eastern Europe: Gauging Three Potential Scenarios", Global Policy, 2017, Say1 31/2, 1-25, s. 16.

${ }^{76}$ Richard Ericson, "The Russian Economy: From Lenin to Putin", Comparative Economic Studies, 2008, Say1 50, 713-716, s. 714.

77 Anders Åslund, "Russia's Economic Transformation under Putin", Eurasian Geography and Economics, 2014, Say1 45, 397-420, s. 415.

${ }^{78}$ Ericson, a.g.e., s. 715.
} 
2009-2017 Arası Küresel Sistemin Güvenlik Dönüşümü:

Tek Kutupluluk Çok Kutupluluğa Karş1

Ancak Putin yönetimi ağırlıklı olarak enerji ürünleri ihracatına dayanan ekonominin çeşitlendirilmesi adına da bazı çalışmalarda bulunmuştur. ${ }^{79}$

Putin'in devlet başkanlığı döneminde elde edilen bu ekonomik başarılar Rusya'nın uluslararası arenada daha belirgin bir aktör haline gelmesine de vesile olmuştur. Putin her ne kadar devlet başkanlığının ilk yıllarında $\mathrm{ABD}$ ile ilişkilerin geliştirilmesine özel bir önem vermişse de Bush yönetiminin tek taraflı politikalar izlemekte ısrarcı olması nedeniyle özellikle 2003-2004 döneminden sonra dış politikada daha Avrasyacı bir çizgiye yaklaşmıştır. ${ }^{80}$

Rusya-ABD ilişkilerindeki kırılmanın en önemli nedeni Putin'in 11 Eylül sonrası dönemde ABD'nin teröre karşı savaşı kapsamında Afganistan'ı işgaline destek vermesine rağmen Bush yönetiminin 2003 yılında BMGK onayını almaksızın ve Rusya'nın itirazlarına rağmen Irak'a askerî müdahalede bulunmasıdır. ABD ayrıca yine Rusya'nın tepkilerine rağmen NATO'nun eski Sovyet coğrafyasına doğru genişlemesini desteklemiştir. Öte yandan 2003-2005 arası dönemde Ukrayna, Gürcistan ve Kırgızistan'da meydana gelen ve Rusya yanlısı yönetimlerin geniş kapsamlı halk gösterileri ile devrilmeleri ile sonuçlanan "renkli devrimler" de Putin yönetimi tarafından ABD'nin eski Sovyet coğrafyasında rejim değişikliği yaratmaya çalışması olarak algılanmıştır. ${ }^{81} \mathrm{Bu}$ gelişmeler Putin yönetiminin Rusya ve ABD

\footnotetext{
${ }^{79}$ Richard Sakwa, Putin: Russia's Choice, Routledge Publishing, NY, 2008, s. 134,157.

80 1998-2004 arasında Duma başkanlığının strateji ve jeopolitik konularında danışmanlığını yapan düşünür Aleksandr Dugin tarafindan ortaya konulan bu görüşe göre: coğrafya, doğa, dil, iklim, kültür ve din açısından Rusya ne Doğu ne de Batı'dır, bağımsız ve özel bir üçüncü yöndür. Konu hakkında daha detaylı bilgi için bkz. Aleksandr Dugin, Rus Jeopolitiği: Avrasyacı Yaklaşım, (Çev. Vügar İmanov), Küre Yayınları, İstanbul, 2010, s. 3, 4.

${ }^{81}$ Renkli devrimler veya çiçek devrimleri, komünizm sonrası Orta ve Doğu Avrupa'ya ve hemen akabinde Orta Asya'ya kadar yayılan bölgede cereyan eden halk hareketlerini toplu olarak ifade eden isimlerdir. Bağımsız Devletler Topluluğu (BDT) ülkelerinden Gürcistan'daki 2003 Gül ve Karanfil Devrimi ve Ukrayna'daki 2004 Turuncu Devrim diğer devrimlerden daha şiddetli gerçekleşmiştir. Bu devrimlerin Rusya'nın arka bahçesi olarak gördüğü coğrafyada gerçekleşmesi önem taşımaktadır. Örneğin, 23 Kasım 2003 tarihinde Gürcistan Devlet Başkanı Eduard Shevardnadze 24 yıllık iktidarının sonunda istifa etmiştir. 4 Ocak 2004 tarihinde yapılan devlet başkanlığı seçimlerinde sivil darbenin lideri, Batı yanlısı Mikhail Saakashvili, rakiplerini açık farkla geçerek \%96,7 oy oranıyla seçimleri kazanmıştır. Yine, 2004 yılında Ukrayna'da meydana gelen gösterilerde Batı'nın desteğiyle devlet başkanlığı koltuğuna Viktor Yushchenko Moskova destekli Yanukovych'i devre dışı bırakmıştır. Bu durum, ABD-Rusya ilișkilerinde dönüm noktası olarak ifade edilmektedir. Konu hakkında daha detaylı bilgi için David Lane, "Coloured Revolution as a Political Phenomenon", Journal
} 
arasında 11 Eylül'den sonra tesis edilen iş birliği ortamını ciddi anlamda sorgulamasına neden olmuştur. ${ }^{82}$

Putin'in 10 Şubat 2007 tarihinde düzenlenen 43. Münih Güvenlik Konferansı'nda yaptığı konuşması Rusya-ABD ilişkileri açısından önemli bir dönüm noktasıdır. ${ }^{83}$ ABD'nin uluslararası ilişkilerdeki tek taraflı ve dayatmacı yaklaşımına ve "hiper güç kullanımına" dayanan politikasına açıkça karşı çıkan Putin, bu konuda ABD yönetimini sert biçimde eleştirmiş, ayrıca NATO'nun genişlemesine karşı olduğunu şu sözlerle bir kez daha ifade etmiştir:

“...Kimse (hiçbir devlet) kendini güvende hissetmemektedir. Çünkü kimse uluslararası hukukun onları koruyacak bir taş duvar gibi olduğunu hissedememektedir. Elbette böyle bir politika silahlanma yarışını teşvik etmektedir... NATO'nun genişlemesinin, birliğin modernleşme süreci ya da Avrupa'nın güvenliği ile hiçbir ilişkisi yoktur. Aksine, bu girişim karşılıklı güven düzeyini azaltan ciddi bir kışkırtmayı temsil etmektedir. Ve bizim bu noktada sorma hakkınız vardır: bu genişleme kime karş1 yapılmaktadır?" 84

Putin'in Münih'te yapmış olduğu bu konuşmadan yaklaşı 18 ay sonra ise Rusya Gürcistan'la savaşarak Çeçenistan'dan sonra bir kez daha askerî gücünü sergilemeye karar vermiştir. ${ }^{85} 2008$ yılının Ağustos ayında patlak veren savaş, Gürcistan'ın ayrılıkçı bölgesi Güney Osetya'yı yeniden kontrolü altına almak için işgaliyle başlamıştır ve Rusya'nın Güney Osetya'yı desteklemek için savaşa katılmasıyla hız kazanmışır. Rusya her ne kadar sivilleri Gürcistan'ın saldırısından korumak amacıyla askerî müdahalede bulunmak zorunda kaldığını iddia etmişse de savaşın esas nedenin 2003'teki Gül Devrimi sonrasında iktidara gelen Mikhail Şaakaşvili'nin Batı yanlısı

of Communist Studies and Transition Politics, 2009, Say1 25/2,113-135, s. 127.

82 Emre Erşen, "Soğuk Savaş Sonrası Dönemde Dünya Siyaseti", Balcı Ali ve Şaban Kardaş, (ed.), Uluslararası Iliş̧kilere Giriş: Teori Kavram ve Konular, Küre Yayınları, İstanbul, 2014, 41-56, s. 47.

${ }^{83}$ Glenn Diesen, EU and NATO Relations with Russia: After the Collapse of the Soviet Union, Routledge, Abingdon, 2016, s. 53.

84 Vladamir Putin Speech and the Following Discussion at the Munich Conferenc on Security Policy", Kremlin Website, 2007, http://en.kremlin.ru/events/president/transcripts/ 24034 (Erişim Tarihi: 06.10.2020).

${ }^{85}$ Hans Mouritzen and Anders Wivel, Explaining Foreign Policy: International Diplomacy and the Russo-Georgian War, Lynne Rienner Publishers, CO, 2012, s. 89. 
2009-2017 Arası Küresel Sistemin Güvenlik Dönüşümü:

Tek Kutupluluk Çok Kutupluluğa Karşı

politikaları ve özellikle 2008'de NATO'nun Bükreş Zirvesi'nde Gürcistan ve Ukrayna'nın üyeliğinin tartışılması olduğu söylenebilir. ${ }^{86}$

8 Ağustos'ta Gürcistan'a karşı büyük çaplı bir kara, hava ve deniz saldırısı başlatan Rusya ayrıca yine Saakaşvili hükümetine karşı bir siber savaş da sürdürmüştür. ${ }^{87}$ Kisa sürede büyük kayıplar veren Gürcistan ordusunun geri çekilme kararı almasına paralel olarak Fransa Cumhurbaşkanı Sarkozy'nin girişimi ile 12 Ağustos'ta ateşkes anlaşması yapılmıştır. Ancak buna rağmen Rusya 26 Ağustos'ta hem Güney Osetya'nın hem de diğer bir ayrılıkçı bölge olan Abhazya'nın Gürcistan'dan bağımsızlığını tanımasıyla Gürcistan-Rusya ilişkileri yeniden gerginleşmiştir.

Gürcistan müdahalesi ile Rusya hem askerî kapasitesini dünyaya sergileme fırsatı bulmuş, hem de bu kapasiteyi kullanmaya hazırlıklı olduğunu göstererek ABD'ye karş1 önemli bir meydan okumada bulunmuştur. ${ }^{88}$ Nitekim Soğuk Savaş sonrası dönemde ilk kez ABD dışında bir ülkenin başka bir ülkeye bu tür bir askerî müdahalede bulunduğunun altını çizmek gerekir. Gürcistan savaşı aynı zamanda Putin'in ardından devlet başkanlığı görevine seçilen Dimitri Medvedev'in karşılaştığı ilk dış politika krizi olması bakımından da önemlidir.

Rusya anayasası aynı kişinin iki dönemden fazla üst üste devlet başkanı seçilmesine izin vermediği için Putin'in önerisiyle devlet başkanlığına aday olan ve 2008'de düzenlenen seçimleri ezici bir oy oranıla kazanan Medvedev'in 2012'ye kadar devam eden başkanlık döneminde Putin'de başbakanlık görevini üstlenmiştir. ${ }^{89}$ Dolayısıyla 2008-2012 dönemini aslında Putin-Medvedev dönemi olarak okumak daha doğru olur.

\footnotetext{
86 "Bucharest Summit Declaration", NATO, https://www.nato.int/cps/en/natolive/official _texts_8443.htm, (Erişim Tarihi: 03.01.2021)

87 Dijital savaşın ilk etabında Gürcistan yönetimine ait web siteleri Rusya tarafindan Dos (distributed-denial-of-service) saldırılarıyla devre dışı bırakılmıştır. Öte yandan resmî sitelerin içeriklerinde de değişiklikler yapılmıştır. Bu nedenle, Rusya-Gürcistan Savaşı klasik çatışma yöntemlerine dijital muharebe yöntemlerinin eşlik ettiği bir savaş olarak tarihe geçmiştir. Bilgi için bkz. Andrei P. Tsygankov and Matthew Tarver-Wahlquist. "Duelling Honors: Power, Identity and the Russia-Georgia Divide", Foreign Policy Analysis, 2009, Say1: 5/4, 307-326, s. 316.

${ }^{88}$ Tsygankov and Tarver-Wahlquist, a.g.e., s. 315, 326.

89 "Rusya Federasyonu Anayasas1". Anayasa. Madde 81. https://www.anayasa.gen.tr/ rusya.htm (Erişim Tarihi: 04.012021)
} 
Bu dönemde Gürcistan'da yaşanan gelişmelere ilave olarak 2008'de hız kazanan küresel ekonomik kriz de Rusya'nın dış politika gündemine damga vurmuştur. Krizle birlikte hızla düşen petrol fiyatlarının da etkisiyle Rus ekonomisi 2009 yılında ciddi bir küçülme yaşamış ve Rusya bu nedenle küresel siyasette Çin'e ve diğer yükselen güçlere daha yakın bir politika izlemeye özen göstermiştir (Şekil 3)..$^{90}$

\section{Şekil 3: Rusya Ekonomisinin Büyüme Oranları ve Ham Petrol Fiyatları $(2000-2009)^{91}$}

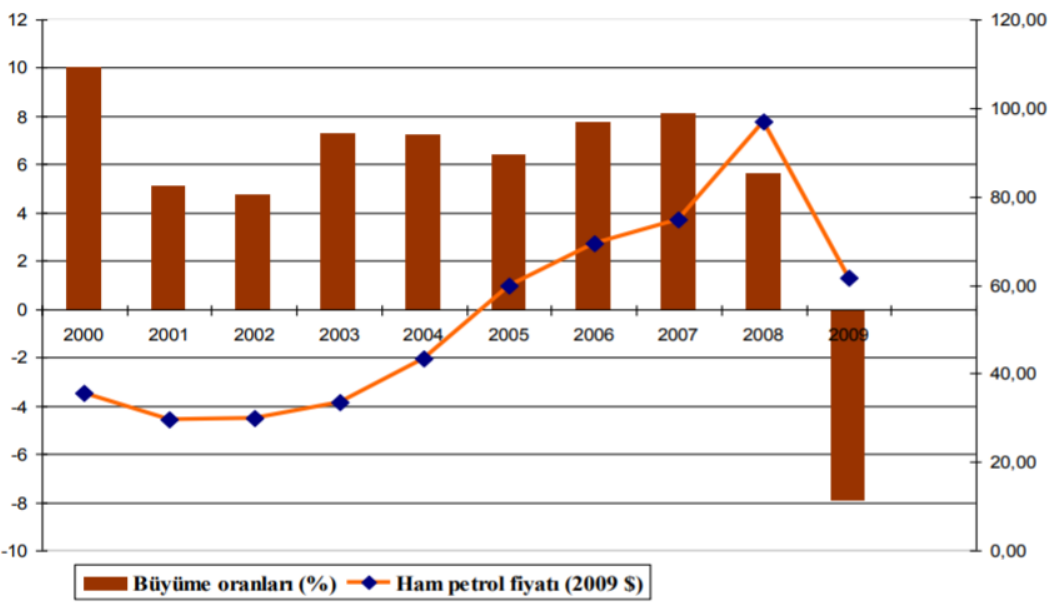

Medvedev'in başkanlık döneminde başlatılan "sıfırlama" politikasına rağmen Rusya ve $\mathrm{ABD}$ arasındaki ilişkilerde Gürcistan savaşı sonrası dönemde çok önemli bir düzelme görülmemiştir. 2012 yılında ise Putin dört senelik aradan sonra yeniden devlet başkanlığ 1 görevine gelmiş, Medvedev de Putin'in yerine başbakanlık görevini üstlenmiştir. Ancak Putin için özellikle 4 Aralık 2011 tarihindeki parlamento seçimleri Batı'yla ilişkiler açısından bir dönüm noktası olmuştur. Putin'in partisi Birleşik Rusya'nın

90 Clifford G. Gaddy and Barry W. Ickes, "Russia after the Global Financial Crisis", Brookings Institute, https://www.brookings.edu/wp-content/uploads/2016/06/05_russia_ financial_crisis_gaddy.pdf (Erişim Tarihi: 07.11.2020)

${ }^{91}$ Büyüme oranları: Dünya Bankası 2001-2009 Rusya Raporları; Ham Petrol Fiyatları: BP, 2010. 
zaferiyle sonuçlanan bu seçimlerde geniş çaplı yolsuzluk yapıldı̆̆ 1 gerekçesiyle binlerce kişinin katılımıyla Rusya'nın farklı şehirlerinde günlerce devam eden Putin karşıtı protesto gösterilerinin Batı tarafından desteklendiği algısı Putin'in ABD ve AB'ye karşı tutumunu sertleştirmesine neden olmuştur. Putin aynı nedenle Avrasya Ekonomik Birliği (AEB) ${ }^{92}$ projesine de hız kazandırarak Rusya'nın eski Sovyet coğrafyasında ekonomik nüfuzunu pekiştirmeye gayret etmiştir. ${ }^{93} 180$ milyondan fazla insanın yaşadığı ve 5 trilyon doların üzerinde bir ekonomik büyüklüğe sahip olan bu bölgede $\mathrm{AB}$ benzeri bir örgütün kurulmasına liderlik ederek Rusya'nın bir anlamda Batı'ya karşı yeni bir meydan okumada bulunduğu söylenebilir. ${ }^{94}$

Daha önce de ifade edildiği gibi BRICS ve ŞīÖ gibi girişimlerde de aktif rol üstlenen Rusya için bu kurumlar aracılığıyla yükselen güçlerle beraber hareket etmek, Batı'yla siyasi alanda rekabet edebilmenin yanı sıra Rusya'nın 2008 sonrasında karşı karşıya olduğu ekonomik engelleri aşabilmesi adına da önem taşımaktadır. Zira 2000’lerde askerî gücünü modernize etme bakımından belli bir başarı elde eden Rusya, ekonomik olarak petrol ve doğalgaz gelirlerine bağımlı durumdadır ve bu enerji ürünlerinin fiyatlarında meydana gelen dalgalanmalara karşı oldukça savunmasızdır. Gerçi 2000 yılında Rusya'nın GSYH açısından dünya sıralamasındaki yeri 19 iken, 2016 yılında 12. sıraya yükseldiği görülmektedir. Diğer bir deyişle bu sürede Rusya GSYİH'sini 4,5 kat arttırmıştır. Ancak Rusya'nın hala BRICS ülkeleri arasında Güney Afrika'dan sonra ekonomisi en küçük ülke olduğunu vurgulamak gerekir. Örneğin 2016 y1lı verilerine göre Rusya ekonomisi ABD ekonomisinin sadece \%7'sine karşllık gelmektedir (Şekil 4). ${ }^{95}$ K1sacası 2000'ler boyunca Rusya ekonomik alanda

\footnotetext{
92 Doğu Avrupa, Orta Asya ve Batı Asya'da bulunan devletlerin ekonomik birliği olan AEB, 29 Mayıs 2014 tarihinde Belarus, Kazakistan ve Rusya liderleri tarafindan imzalanmış ve 1 Ocak 2015 tarihinde yürürlüğe girmiştir. Ermenistan ve Kırgızistan'ın Avrasya Ekonomik Birliği'ne katılımını amaçlayan anlaşmalar sırasıyla 9 Ekim ve 23 Aralık 2014 tarihlerinde imzalanmıştır. AEB, mal ve hizmetlerin serbest dolaşımını teşvik etmektedir. Ayrıca, ulaştırma, sanayi ve tarım, enerji, dış ticaret, yatırım ve gümrük düzenlemelerinde ortak politikalar sağlamaktadır. Yakın gelecekte birlik içinde tek para birimi kullanımını da içeren daha fazla entegrasyon hükümlerinin uygulanması öngörülmektedir.

93 Erşen, a.g.e., s. 54.

${ }^{94}$ Serdar Y1lmaz, "Eurasian Economic Union: A Regional Economic Hegemony Initiative", Journal of Eastern European and Central Asian Research, 2019, Say1 4/10, 1-13, s. 10.

${ }^{95}$ Roger E. Kanet, Russia: Re-Emerging Great Power, Palgrave Macmillan, New York,
} 
belli bir başarı göstermişse de bu alanda küresel bir oyuncu olmaktan uzaktır. Bu nedenle, Rusya'nın Çin ile ortaklığını pekiştirerek küresel alandaki etkisini muhafaza etmeye çalıştığı söylenebilir.

\begin{tabular}{|c|c|c|c|c|}
\hline & amasınc & la Rus & GSYH $)^{96}$ & \\
\hline & 20 & & 201 & \\
\hline & USD & Rank & USD & Rank \\
\hline USA & 10285 & 1 & 18569 & 1 \\
\hline Japan & 4887 & 2 & 4939 & 3 \\
\hline Germany & 1956 & 3 & 3467 & 4 \\
\hline China & 1215 & 6 & 11218 & 2 \\
\hline Brazil & 655 & 10 & 1799 & 9 \\
\hline India & 477 & 13 & 2256 & 7 \\
\hline Russia & 279 & 19 & 1281 & 12 \\
\hline
\end{tabular}

Putin'in üçüncü başkanlık dönemi olan 2012-2018 döneminde ise ABD-Rusya ilişkileri özellikle Doğu Avrupa ve Orta Doğu bölgelerinde yaşanan gelişmeler nedeniyle hızla gerginleşmiştir. Doğu Avrupa ile ilgili olarak NATO ve AB'nin bir zamanlar Sovyetler Birliği'nin parçası olan ülkelere doğru genişlemeye devam etmesi Rusya'yı rahatsız etmiştir. Bu rahatsızlık Ukrayna örneğinde en üst seviyeye ulaşmıştır. Zira özellikle 2011'den sonra Rusya Ukrayna hükümetine AEB'ye katılması için baskı yaparken, Batı yanlısı muhalefet partileri ise $A B$ ile anlaşma yapılması gerektiğini savunmuşlardır. Bu konu nedeniyle 2014 yılında Ukrayna'da bir kez daha patlak veren hükümet karşıtı halk gösterileri sonucunda ülkede meydana gelen iktidar değişikliği ise Putin yönetimi tarafından Batı destekli bir darbe olarak değerlendirmiştir. Rusya bu gelişmelere tepki olarak Kırım'ı ilhak etmiş ve Ukrayna'dan ayrılmak isteyen Donbass bölgesindeki Rusya yanlısı gruplara da destek vermiştir. Ayrıca bu süreçle bağlantılı olarak $A B$ ve $A B D$ tarafından kendisine karşı başlatılan ekonomik yaptırımlara misilleme olarak hibrit savaş taktiklerini

2007, s. 256.

${ }^{96} \mathrm{IMF}$, https://www.principalglobalindicators.org/?sk (Erişim Tarihi: 23.07.2020) 
2009-2017 Arası Küresel Sistemin Güvenlik Dönüşümü:

Tek Kutupluluk Çok Kutupluluğa Karş1

öne çıkarmıştır. ${ }^{97}$ Sonuç olarak Ukrayna meselesi bugün dahi Rusya-Batı ilişkilerinde önemli bir jeopolitik kriz alanı oluşturmaya devam etmektedir. ${ }^{98}$

\section{Sonuç}

ABD'nin liderlik ettiği küresel sistemdeki istikrarsızlığın ilk belirtileri 11 Eylül 2001 saldırılarıyla gözlemlenmiş, düzenlenen bu saldırılar ile “ABD'nin dokunulmazlığı” algısı yeniden şekillenmiştir. Bu saldırıların akabinde Bush yönetimi tarafından başlatılan Afganistan ve Irak savaşları başarıya ulaşamamış ve bu durum ABD'nin maddi ve ahlaki gücünün dünya çapında erimesine neden olmuştur. Özellikle 2008 yılında patlak veren ekonomik kriz, ABD'nin oluşumuna liderlik ettiği uluslararası kurumları yönetme kapasitesindeki eksikliği gözler önüne sermiştir. Uluslararası sistemde Çin'in yükselişi, Rusya'nın güç restorasyonu ve BRICS'in kuruluşu gibi gelişmeler ise Amerikan hegemonyasından çok kutuplu dünya düzenine geçiş sürecini daha belirgin hale gelmiştir. $\mathrm{Bu}$ süreçte, yapısal güç dinamikleri açısından en önemli gelişmenin Çin'in artan gücü olduğu tespit edilmiştir. Rusya'nın ise askerî modernizasyon süreci ile beraber küresel nüfuzunun belirginleştirdiği ve ŞïÖ ve BRICS gibi oluşumlar aracilığıyla Çin ile entegrasyonunu derinleştirmesinin ülkeye önemli bir dengeleme potansiyeli kazandırdığı görülmüştür.

İncelenen gelişmeler 1şığında uluslararası sistemde Amerikan hegemonyasına karşı Çin'den ve belli alanlarda Rusya'dan önemli meydan okumalar geldiği, ancak hem sert hem yumuşak güç unsurları açısından hala $\mathrm{ABD}$ ile eşleşmiş konumda bir büyük gücün olmadığ tespit edilmiştir. Mevcut eğilimlere dayanarak Çin'in, Rusya'nın güncel revizyonist davranışından farklı olarak bir gün uluslararası sistemde ABD ile rekabet edebilecek kapasiteye ulaşması beklenmektedir. Öte yandan ABD'nin 2003'te gerçekleşen Irak Savaşı'nın ardından kademeli olarak küresel boyutta üstlendiği rolden çekilmek zorunda kalmasının sadece hegemonik düşüş olarak değil, yorgunluk işareti olarak da tanımlanabileceği belirtilmelidir.

\footnotetext{
97 Alexander Lanoszka, "Russian Hybrid Warfare and Extended Deterrence in Eastern Europe”, International Affairs, 2016, Say1 92, 175-195, s. 189.

98 Alexander Motyl J., "Putin's Zugzwang: The Russia-Ukraine Standoff", World Affairs, 2014, Say1 177/2, 58-65, s. 61.
} 
Zira ABD'nin askerî, teknoloji, ekonomi ve enerji alanlarındaki potansiyeli göz önüne alındığında, çok kutupluluğa geçiş sürecinin oldukça yavaş gerçekleştiği görülmektedir. Bu bakımdan, ABD’nin hegemonik düşüşünün vazgeçilmez bir sonuç olarak değil, yeniden canlandırılabilir bir durum olarak da değerlendirilebileceği sonucuna ulaşılmıştır.

\section{Summary}

After the Cold War, the US, as the only superpower in the system, created a hegemonic system through alliances, institutions, and geopolitical negotiations. In this new world order, the US has positioned itself at the center of world politics by taking advantage of its military power, regional alliances, and cultural soft power. In this unipolar system, international norms, human rights, financial system, and the behaviors of the governments are largely designed and owned by the US and these practices have spread to the political and legal spheres of other states. However, since the 2000s the new developments in the international system leads to slow but gradual redistribution of the power, which was under the US monopoly. In this context, this study examines the important developments that point out to weakening of unipolarity in the international system between 2009 and 2017, known as the Obama era, with the theoretical framework of neoclassical realism.

The 9/11 attacks and the failure of the US in the interventions in Iraq and Afghanistan showed that the transition from American hegemony to multipolar world order has started. This process was further accelerated with developments such as the rise of China, Russia's power restoration, and the establishment of BRICS. Especially the 2008 economic crisis puts forward that the US lacks the capacity to manage the international institutions. In this context, the transformation process of unipolarity in the international system is analyzed in the context of the reflections of the global economic crisis, the rise of China as a global actor, and the prominence of Russia's global influence.

It has been concluded that the most important development in terms of structural power dynamics is China's increasing power. China initiated major development projects in various fields such as economy, military, technology, software, and infrastructure. On the other hand, it has been revealed that Russia's global influence has been increased with the military modernization 
process, but its soft power capabilities are still following a downward trend. In this respect, it has been observed that the integration initiations of Russia with China, such as SCO and BRICS have given Russia an important power balancing potential in the international system.

In the light of these developments, it has been determined that there have been significant challenges in certain areas from China and Russia against American hegemony in the international system, but still, there is no big power that is paired with the US in terms of both hard and soft power elements. Considering the potential capacity of the USA in the fields of military, economy, technology, and energy sectors, it should be stated that the transition to multipolarity is a very slow process. Based on current trends, it is expected that China will one day reach the capacity to compete with the US in the international system, unlike Russia's current revisionist behaviors. On the other hand, the USA's gradual withdrawal from its global role after the Iraq War in 2003 can be considered not only as a hegemonic decline but also as a sign of fatigue. For this reason, the hegemonic decline of the USA can be considered not as an indispensable result, but also as a revivable situation. In conclusion, the developments in the international system between 2009 and 2017 show that the structural transition of the international system continues and in this transition period the Sino-US relations have competitive potential.

\section{Çatışma Beyanı:}

Makalenin ile ilgili herhangi bir kurum, kuruluş, kişi ile çıkar çatışması bulunmamaktadir.

\section{Kaynakça}

Kitaplar ve Kitap Bölümleri

ACHARYA, Amitav, Regional Worlds in a Post-Hegemonic Era, Spirit Working Papers, Bordeaux, 2009.

Cornell University Press, Ithaca, 2010.

AMIN, Samir, Beyond US Hegemony? Assessing the Prospects for a Multipolar World, Zed Books, New York, 2006.

BRADFORD, Colin Bradford and WONHYUK, Lim, Global Leadership in Transition: Making the G20 More Effective and Responsive, Brookings Institution Press, 2011. 
DAVIDSON, Jason, America's Allies and War, Palgrave Macmillan, Basingstoke, 2011.

DIESEN, Glenn, EU and NATO Relations with Russia: After the Collapse of the Soviet Union, Routledge, Abingdon, 2016.

DUECK, Colin, Neoclassical Realism and the National Interest: Presidents, Domestic Politics, and Major Military Interventions, Cambridge University Press, Cambridge, 2009.

DUGIN, Aleksandr, Rus Feopolitiği: Avrasyacı Yaklaşım, (Çev. Vügar İmanov), Küre Yayınları, İstanbul, 2010.

ERŞEN, Emre, "Soğuk Savaş Sonrası Dönemde Dünya Siyaseti”, Balcı Ali ve Şaban Kardaş, (ed.). Uluslararası Illişkilere Giriş: Teori Kavram ve Konular, Küre Yayınları, İstanbul, 2014.

GILPIN, Robert, Global Political Economy: Understanding the International Economic Order, Princeton University Press, Princeton, 2001.

HOOK, Steven and SPAINER, John, American Foreign Policy Since World War II, CQ Press, Washington, 2009.

HUIMIN, Ma, "Strategic Plan of "Made in China 2025" and its Implementation", IGI Global, 2018.

KANET, Roger E., Russia: Re-Emerging Great Power, Palgrave Macmillan, New York, 2007. KEOHANE, Robert O., After Hegemony: Cooperation and Discord in the World Political Economy, Princeton University Press, Princeton, 1984, s.46.

KHANNA, Parag, The Future is Asian: Global Order in the Twenty-first Century, Weidenfeld \& Nicolson, London, 2019.

MOURITZEN, Hans and WIWEL, Anders. Explaining Foreign Policy: International Diplomacy and the Russo-Georgian War, Lynne Rienner Publishers, COA, 2012.

SAKWA, Richard, Putin: Russia's Choice, Routledge Publishing, NY, 2008.

SALZMAN, Rachel S., Russia, BRICS, and the Dismuption of Global Order, Georgetown University Press, Washington, 2019.

WALT, Stephen M., The Origins of Alliance, Cornell University Press, NY, 1987.

WHITE Stephen, Understanding Russian Politics, Cambridge University Press, Cambridge, 2011.

ZAKARIA, Fareed, The Post-American World And The Rise Of The Rest, Penguin Books, London, 2008.

Makaleler

ACHARYA, Amitaw, "After Liberal Hegemony: The Advent of a Multiplex World Order”. Ethics $\mathcal{E}$ International Affairs, 2017, Say1 31/3, 271-285.

-, The End of American World Order, Polity, Cambridge, 2018, 19-27.

AMBROSIO, Thomas, "Catching the 'Shanghai Spirit': How the Shanghai Cooperation Organization Promotes Authoritarian Norms in Central Asia”, Europe-Asia Studies, 2008, Say1 60/8, 1321-1344.

ASLUND, Anders, "Russia's Economic Transformation under Putin", Eurasian Geography and Economics, 2014, Say1 45, 397-420.

BANDI, Ram Prasad, "BRICS: International Financial Crisis and Challenges of Governance", Conference: International Symposium on Building Governance Systems And Capabilities Of BRICS Countries, 2014, 2-20.

BROOKS, Stephen G., "Reshaping the World Order", Foreign Affairs, 2009, Say1 88/2, 49-63.

COX, Robert, "Social Forces, States and World Orders: Beyond International Relations Theory”, Millennium Fournal of International Studies, 1981, Say1 10/2, 126-155. 
2009-2017 Arası Küresel Sistemin Güvenlik Dönüşümü:

Tek Kutupluluk Çok Kutupluluğa Karşı

ERICSON, Richard, “The Russian Economy: From Lenin to Putin”, Comparative Economic Studies, 2008, Say1 50, 713-716.

ERŞEN, Emre, “Neo-Eurasianism and Putin's 'Multipolarism' in Russian Foreign Policy", Turkish Rewiew of Euroasian Studies, 2004, Say1 4, 135-172.

2014, 1-9.

GODDARD, John, and WILSON, John, “The Financial Crisis in Europe: Evolution, Policy Responses and Lessons for the Future", Fournal of Financial Regulation and Compliance, 2009, Say1 17, 362-380.

GONTHIER, Frédéric and MATTHEWS, Toby, “The Rise of Interventionism in the European Union and its Social Foundations: An Analysis of Economic Attitudes between 1990 and 2008”, Reoue Française De Sociologie (English Edition), 2015, Say1 56/1, 1-38.

HAAS, Richard N., "The Age of Nonpolarity: What will Follow US Dominance?", Foreign Affairs, 2008, Say1 87/3, 44-56.

KAKONEN, Jyrki, "BRICS as a New Power in International Relations?", Geopolitics, History, and International Relations, 2014, Say1 6/2, 85-104.

KO, Sangtu, "Strategic Partnership in a Unipolar System: The Sino-Russian Relationship", Issues $\mathcal{E}$ Studies, 2006, Say1 42/3, 203-225.

LANE, David, "Coloured Revolution as a Political Phenomenon", Fournal of Communist Studies and Transition Politics, 2009, Say1 25/2, 113-135.

LANOSZKA, Alexander, "Russian Hybrid Warfare and Extended Deterrence in Eastern Europe”, International Affairs, 2016, Sayı 92, 175-195.

LAYNE, Christopher, "The Unipolar Illusion: Why New Great Powers will Rise", International Security, 1993, Say1 17/4, 5-51.

LEVINE, Derek Adam, "Made in China 2025: China's Strategy for Becoming a Global High-Tech Superpower and its Implications for the U.S. Economy, National Security, and Free Trade", Journal of Strategic Security, 2020, Say1 13/3, 1-16.

MAGALHAES, Pedro, "Financial Crisis, Austerity, and Electoral Politics", Fournal of Elections Public Opinion E Parties, 2014, Say1 24, 125-133.

MAHBUBANI, Kishore, "The Not-So-Surprising Rise of China and India”, fournal of International Affairs, 2011, Say1 64/2, 221-226.

MEARSHEIMER, John, "The Gathering Storm: China's Challenge to US Power in Asia”, The Chinese Fournal of International Politics, 2010, Say1 3/4, 381-396.

MORRIS, Justin and WHEELER, Nicholas J., "The Security Council's Crisis of Legitimacy And The Use Of Force”, International Politics, 2007, Say1 44/2.

MOTYL, Alexander J., "Putin's Zugzwang: The Russia-Ukraine Standoff”, World Affairs, 2014, Say1 177/2, 58-65.

RADULESCU, Irina, MIRELA Panait and VOICA Catalin, "BRICS Countries Challenge to the World Economy New Trends", Procedia Economics and Finance, 2014, Say1 8, 604-613.

RANDALL, Germain, "Financial Order and World Politics: Crisis, Change and Continuity", International Affairs, 2009, Say1 85/4, 669-687.

SAKWA, Richard, "New Cold War or Twenty Years Crisis?: Russia and International Politics", International Affairs, 2008, Sayı 2, 241-267.

SCHWELLER, Randall L., "New Realist Research on Alliances: Refining, not Refuting, Waltz's Balancing Proposition", The American Political Science Review, 1997, Say1:91/4, 927-930. 
Orders", Valdai Paper, Sayı 16, 2015, 16-29.

SERFATY, Simon, "Moving into a Post-Western World”, The Washington Quarterly, 2011, Say1 34/2, 7-23.

SHOMALI, Hamid and GIBBLIN, Gwendolyn, "The Great Depression and the 20072009 Recession: The First Two Years Compared”, International Research fournal of Finance and Economics, 2010, Say1 59, 15-22.

SMITH, Nicholas Rose, "Assessing the Trajectory of West-Russia Relations in Eastern Europe: Gauging Three Potential Scenarios”, Global Policy, 2017, Say1 31/2, 1-25.

STRONSKI, Paul and SOKOLSKY, Richard, "SCO: Multipolarity in Practice: Understanding Russia's Engagement with Regional Institutions”, Carnegie Endowment for International Peace Report, 2020. 11-18.

TALVING, Liisa, "Economic Voting in Europe: Did the Crisis Matter?", Comparative European Politics, 2017, Say1 10, 1-30.

THAKUR, Ramesh, "How Representative are BRICS?", Third World Quarterly, 2014, Say1 35/10, 1791-1808.

TSYGANKOV, Andrei P. and TARVER-WAHLQUIST, Matthew, "Duelling Honors: Power, Identity and the Russia-Georgia Divide”, Foreign Policy Analysis, 2009, Say1 5/4, 307-326.

WAEVER, Ole, "International Leadership after the Demise of the Last Superpower: System Structure and Stewardship", Chinese Political Science Review, 2017, Sayı 2/4, 452-476.

WALT, Stephen M., “Alliances in a Unipolar World”, World Politics, 2009, Say1 61/1, 86-120. WOHLFORTH, William, "Russia's Soft Balancing Act", Strategic Asia Fragility and Crisis, 2003, Say1 4, 165-179.

YILMAZ, Serdar, "Eurasian Economic Union: A Regional Economic Hegemony Initiative", Fournal of Eastern European and Central Asian Research, 2019, Say1 4/10, 1-13. Internet Kaynakları

"EU Negotiating Texts in TTIP", Europa, https://trade.ec.europa.eu/doclib/press/ index.cfm? $\mathrm{id}=1230$ (Erişim Tarihi: 30.05 .2020 )

IMF, https://www.principalglobalindicators.org/?sk (Erişim Tarihi: 23.07.2020)

"Putin: Unipolar World Unacceptable to Russia", Republica, https://www.republika. co.id/amp_version/njfzxy (Erişim Tarihi: 11.12.2020)

"Rusya Federasyonu Anayasası", Anayasa, Madde 81, https://www.anayasa.gen.tr/ rusya.htm (Erişim Tarihi: 04.012021)

"SCO Explores Global Governance for New Era", Global Times, http://www.globaltimes.cn/content/1106373.shtml (Erişim Tarihi: 19.09.2020)

"Shifting Balance Of Power", Europa, https://ec.europa.eu/knowledge4policy/foresight/topic/ changing-security-paradigm/changing-nature-balance-power (Erişim Tarihi: 19.09.2020)

"The Commission's Intervention in the Greek Financial Crisis", Europa, https://op.europa.eu/webpub/eca/special-reports/greek-crisis-17-2017/en/ (Erişim Tarihi: 28.05.2020)

"Vladamir Putin Speech and the Following Discussion at the Munich Conferenc on Security Policy", Kremlin Website, http://en.kremlin.ru/events/president/ transcripts/24034 (Erişim Tarihi: 06.10.2020).

“2020 Country Brief: China”, Third Way, www.jstor.org/stable/resrep26161 (Erişim Tarihi: 05.05.2020) 
2009-2017 Arası Küresel Sistemin Güvenlik Dönüşümü:

Tek Kutupluluk Çok Kutupluluğa Karşı

World Economic Outlook Database-PPP Adjusted GDP Shares, IMF, Report for Selected Countries and Subjects (imf.org), https://www.imf.org/en/Publications/WEO/ weo-database/2020/October/weo-report?c $=513,514,516$ (Erişim Tarihi: 01.01.2021) BENNER, Katie, "China's Dominance Of 5G Networks Puts US Economic Future at Stake, Barr Warns", NY Times, "https://www.nytimes.com/2020/02/06/us/politics/barr5g.html (Erişim Tarihi: 07.05.2020)

GADDY, Clifford G. and ICKES, Barry W, "Russia after the Global Financial Crisis", Brookings Institute, https://www.brookings.edu/wpcontent/uploads/2016/06/05 russia_financial_crisis_gaddy.pdf (Erişim Tarihi: 07.11.2020)

GALLOWEY, Lindsay, "Five Superpowers Rulling the World In 2020", BBC News, http://www.bbc.com/travel/story/20200322-five-superpowers-ruling-the-world-in-2050 (Erişim Tarihi: 07.05.2020)

JOHNSON, Keith, "Why is China Buying up Europe's Ports?", Foreign Policy Report, https://foreignpolicy.com/2018/02/02/why-is-china-buying-up-europes-ports/ (Erişim Tarihi: 07.05.2020)

KRASTEV, Ivan, “Sovereign Democracy' Russian-Style”, Insight Turkey, 2006, Sayı 8/4, 113-117.

MCBRIDE, James and CHATZKY Andrew, "Is 'Made in China 2025' a Threat to Global Trade?", Council on Foreign Relations, https://www.cfr.org/backgrounder/madechina-2025-threat-global (Erişim Tarihi: 03.07.2020)

YUEN, Yuen Ang, "Demystifying Belt and Road The Struggle to Define China's "Project of the Century", Foreign Affairs, https://www.foreignaffairs.com/articles/ china/2019-05-22/demystifying-belt-and-road (Erişim Tarihi: 06.05.2020)

ZAKARIA, Fareed, "How to Deal with China", Newsweek, https://www.newsweek.com/ fareed-zakaria-how-handle-china-87711 (Erişim Tarihi: 03.06.2020)

ZAKARIA, Fareed, "The Rise of The Rest", Newsweek, https://fareedzakaria.com/ columns/2008/05/12/the-rise-of-the-rest (Erişim Tarihi: 03.05.2020) 